\title{
A Sociedade de Instrução e Beneficência A Voz do Operário Outra forma de fazer política: a propósito da reforma dos serviços escolares (1924-1935) ${ }^{1}$
}

\author{
"A Sociedade de Instrução e Beneficência A Voz do Operário" \\ Another way of doing politics: on the reform of school services (1924-1935) \\ "A Sociedade de Instrução e Beneficência A Voz do Operário" \\ Otra forma de hacer política: sobre la reforma de los servicios escolares (1924-1935)
}

\author{
Filomena Bandeira \\ Universidade Nova de Lisboa (Portugal) \\ https://orcid.org/0000-0002-3917-5743 \\ band.lisboa@gmail.com
}

\section{RESUMO}

Este artigo insere-se num projeto sobre Escolas e experiências de referência em Portugal no século $X X$ e centra-se no estudo de uma instituição que desenvolve atividades educativas num quadro associativo e para as classes populares. Optámos por uma apresentação descritiva com a intenção de argumentar que a adoção e aplicação de um modelo educativo, inspirado na Educação Nova e conformado a um público específico, assentou numa estratégia sociopolítica, emergente das condições históricas do associativismo operário na primeira metade do século XX e da situação vivida no País com a crise da Primeira República, que desembocou no Estado Novo. No artigo explanamos o processo de reforma dos serviços escolares da Voz do Operário entre 1924-1935, não sem antes apresentarmos uma história sumária da Sociedade, desde o fim do século XIX até à década de 1950, com o objetivo de representar a associação na sua dimensão, atividade e significado social.

Palavras-chave: Associativismo operário. Educação Nova. Portugal.

\footnotetext{
${ }^{1}$ Investigação inserida no Projeto: INOVAR - Roteiros da inovação pedagógica: Escolas e experiências de referência em Portugal no século XX, PTDC/MHC-CED/0893/2014, financiado através de fundos nacionais da FCT/MCTES-PT. A autora é candidata ao doutoramento, inserido no programa "Diversidad, Subjetividad y Socialización. Estudios en Antropología Social, Historia de la Psicología y de la Educación”, Escuela de Doctorado de la Universidad Nacional de Educación a Distancia, UNED (España).
} 


\begin{abstract}
This article is part of a project about schools and experiences of reference in Portugal in the 20th century. It focuses on the study of Voz do Operário, an institution that developed educational activities for the lower classes in an associative context. We opted for a descriptive presentation with the intention of arguing that the adoption and application of an educational model - inspired by the New Education (Educação Nova) and aimed at a specific audience was based in a socio-political strategy, which emerged both from the historical conditions of workers' associativism in the first half of the 20th century, and from the situation Portugal was living due to the crisis of the First Republic, which would lead to the the New State (Estado Novo). In the article, we explain the reform process which was undertaken in the educational services of Voz do Operário between 1924 and 1935. Beforehand, we present a brief history of Portuguese society from the end of the 19th century until the 1950s, to give a representation of the worker's association in its dimension, activity and social meaning.
\end{abstract}

Keywords: Worker's Associativism. New Education. Portugal.

\title{
RESUMEN
}

Este artículo es parte de un proyecto de investigación sobre el tema Itinerarios de innovación pedagógica: escuelas y experiencias de referencia en Portugal en el siglo XX. Se centra en el estudio de una institución que desarrolló actividades educativas en un marco asociativo dirigido a las clases populares. A través de la descripción de esta institución argumentamos que la adopción y aplicación de un modelo educativo, inspirado en la Escuela Nueva y dirigido a un público específico, se basó en una estrategia sociopolítica surgida de las condiciones históricas del asociacionismo obrero en la primera mitad del siglo XX, así como de la situación vivida en el país con la crisis de la Primera República y el advenimiento del Estado Novo. En el artículo exploramos el proceso de reforma de los servicios escolares de la Voz do Operário [Voz del Obrero] desde 1924 hasta 1935, incluyendo previamente una historia sucinta de la Sociedad de Instrucción y Beneficência desde finales del siglo XIX hasta la década de 1950. Con ello pretendemos mostrar a la asociación en su dimensión, actividad e importancia social.

Palabras clave: Asociacionismo obrero. Escuela Nueva. Portugal. 


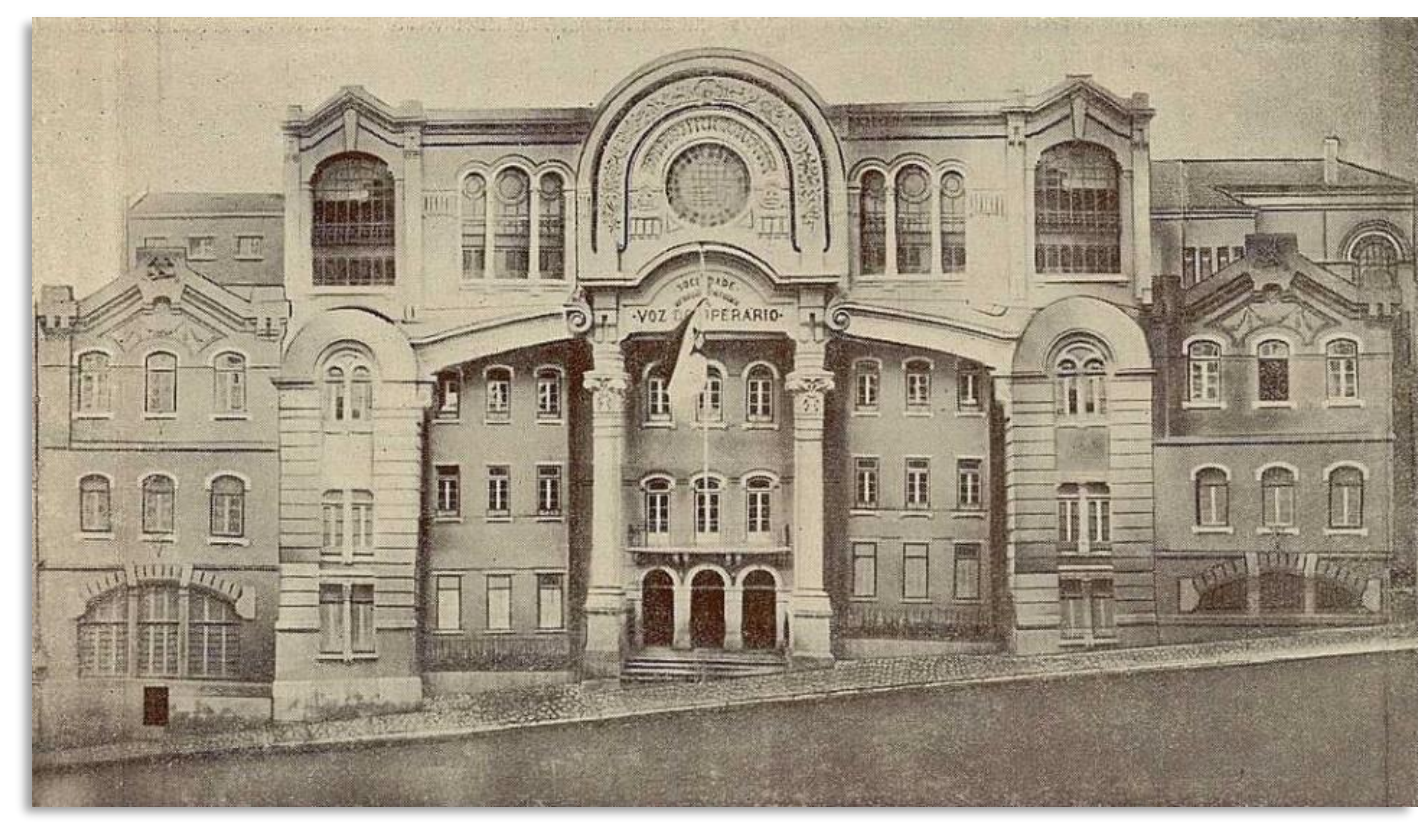

A VOZ DO OPERÁRIO ${ }^{2}$

\section{Introdução}

No cerne deste artigo está uma associação, designada Sociedade de Instrução e Beneficência A Voz do Operário, fundada na última década do século XIX e que se manteve em atividade, ininterruptamente, até aos dias de hoje. A sua ação irradiou a partir da sede, instalada no bairro da Graça, em Lisboa, com morada fixa, a partir de dezembro de 1923, na rua já então denominada de $A$ Voz do Operário e no edifício que a Sociedade havia mandado construir para ser uma grande "Casa dos Trabalhadores". Mas, sob a constância de uma ação e de um trajeto longevo, vivificam múltiplas problemáticas entrelaçadas que importam para o conhecimento e interpretação desta instituição, cujo percurso não é linear, nem isento de tensões, de lutas e de compromissos, independentemente dos ângulos adotados para a observar: o do movimento associativo; o das experiências educativas; e o das modalidades de assistência social.

A investigação que originou o presente artigo insere-se num projeto mais vasto designado INOVAR -, que reúne diversos grupos de investigação pertencentes a diferentes universidades portuguesas, focado no estudo de modelos de educação experimentais, inovadores ou alternativos, sendo selecionadas para o efeito diversas instituições escolares e experiências pedagógicas inscritas naqueles critérios e que tomaram forma na nossa contemporaneidade.

No caso da Voz do Operário, não se optou, como seria, provavelmente, expectável, por dissociar a análise pelo ângulo do programa e práticas educativas - uma das vertentes de intervenção da associação - mas antes colocar no centro a articulação dinâmica entre: associação, como forma de organização, com processos decisórios confiados a uma assembleia geral de sócios; educação, tentando identificar as opções programáticas em relação com os propósitos educativos e a forma como se convocou, ou não, um modelo pedagógico inovador; e assistência social, analisando em particular as modalidades de apoio escolar, pensadas para facilitar o acesso à educação.

\footnotetext{
${ }^{2}$ AHS-ICS: Espólio Pinto Quartin, s.d. [193--], PT-AHS-ICS-PQ-DOC-335.
} 
Nas sociedades modernas, liberais, industrializadas e urbanas, surgem novas práticas de sociabilidade que se expressam através do associativismo, «formas de organização de interesses e de participação cívica da nova ordem política» (Lousada 2017, 97). A Voz do Operário participa neste movimento, especialmente ativo no fim do século XIX e na Primeira República (Melo, 2008). Num universo composto por diferentes tipos de associações (de educação, científicas, culturais, mutualistas e profissionais ou de classe), referenciadas a correntes ideológicas e políticas, A Voz do Operário inscreve-se no associativismo que defende os interesses de grupos profissionais operários, numa perspetiva de classe, politicamente não assumida, mas onde confluem militâncias e sensibilidades socialistas, anarquistas, sindicalistas e republicanas. E em todas elas existiam elementos pertencentes à organização maçónica. Dentro da defesa dos interesses de classe, quer como forma de consciencialização dos fenómenos sociais, quer como estratégia de combate ao analfabetismo ou de acesso à escolarização, quer ainda como qualificação profissional do operário, a educação emergiu como uma aposta da associação, estribada em modalidades de apoio social. Estas as coordenadas que enquadraram a investigação. Quanto ao período cronológico, escolheu-se aquele onde o debate em torno da reforma dos serviços de educação e a elaboração de um programa pedagógico para a estrutura educativa da Sociedade se configurou dentro das premissas do projeto, ou seja, entre os anos 1924/25 e 1935, coincidentes com o fim da Primeira República e o início do Estado Novo. Trata-se, como se verá, de um período efervescente de ideias e de experiências tomadas da Educação Nova, que mobilizam organizações operárias, instituições republicanas e libertárias de educação popular, associações educativas e de professores, iniciativas governamentais e municipais e que contaminam o projeto educativo da Sociedade, numa síntese original, por ser tutelado por uma associação de trabalhadores com um sentido de transformação social. Estende-se a análise até ao início dos anos 50 do século XX com a intenção de auscultar, num novo enquadramento de regulação estatal da instituição, a aplicação do programa e do regulamento aprovados.

\section{Crónicas institucionais e narrativas académicas}

Na passagem da década de 1920 para a de 1930, A Voz do Operário preparava-se para celebrar o cinquentenário com um programa de celebrações especialmente cuidado. Reconhecendo-se que a sociedade não tinha uma história escrita foi decidido, em assembleia geral, no ano de 1929, que se procedesse à redação de uma monografia. Pretendia a administração superar as notas pontuais, de cariz memorialístico e baseadas na tradição oral, geralmente produzidas em discursos ou em artigos publicados no jornal da Sociedade por ocasião da celebração do seu aniversário, pelo investimento numa investigação histórica, «firmada no estudo circunstanciado das atas, coleção do jornal, correspondência e documentos existentes no seu arquivo». Ou seja, à tradição oral, que a passagem do tempo adulterava, sobrepunha-se uma investigação baseada em fontes documentais «de onde deveria brotar a verdade histórica» sobre «a maior realização dos trabalhadores portugueses» (Santos 1938, 97).

Esta iniciativa gorou-se. Mas na gerência de 1930-1931, retomou-se, cabendo ao então presidente do Conselho Fiscal, Raúl Esteves dos Santos ${ }^{3}$, o encargo do estudo, da escrita e da divulgação da história de $A$ Voz do Operário: com este fim, transportou para a sua «residência os livros de atas da comissão administrativa, conselho fiscal e assembleia geral, assim como os

\footnotetext{
${ }^{3}$ O publicista Raúl Esteves dos Santos (1889-1954), sócio de A Voz do Operário, começou a colaborar com os corpos gerentes da associação em 1925, ano em que elaborou um plano reformista para a instituição. Em 1929-1930, foi eleito para o conselho fiscal, e entre 1931 e 1937, para os cargos de presidente da comissão administrativa e da mesa da assembleia geral. Sucederam-se outras prestações, nos mesmos cargos, entre 1941 e 1948 (SIBVO, Assembleia Geral, Livro de Atas, para os anos 1925-1950). Para outros elementos biográficos, vd. p. 207 do presente texto.
} 
documentos que alguma luz pudessem fazer e a volumosa coleção do jornal» (Santos 1938, 98). Entre 1931 e 1944, não deixou de escrever e de publicar textos sobre a história da Sociedade ${ }^{4}$.

Raúl Esteves dos Santos foi o seu cronista. Estabeleceu factos e caracterizou períodos, identificou protagonistas (Esteves 1936b) iluminou dificuldades e combates e referenciou documentos de prova das situações descritas. Para as fases mais recentes da vida da Sociedade, em particular a partir de 1925, Esteves dos Santos integrou na crónica histórica a sua própria experiência, envolvida com a direção da Sociedade e com um programa de ação que revitalizasse A Voz do Operário (Esteves 1933b). Com a recuperação da memória e a construção da história de uma obra feita por trabalhadores para trabalhadores em nome da justiça e progressos sociais, substantivou a identidade de A Voz do Operário com um poderoso sentido imagético: Catedral do Bem, Colmeia, Seara de Luz e Epopeia dos Humildes 5 .

A leitura da história da associação é, naturalmente, conduzida do interior da própria instituição e por um dos seus, com posições vinculadas à defesa do associativismo operário e da capacidade diretiva dos trabalhadores, num discurso semeado de romantismo, que se acentua quanto mais o autor recua na história da Sociedade (os tempos fundadores). Todos estes textos foram publicados, na sua maioria, sob a chancela de A Voz do Operário, e assumiam-se mesmo como «os maiores e melhores instrumentos de propaganda» da Sociedade (Brocas, 1938, 34). Com efeito, a associação para manter o seu programa e quadro de atividade, e muito em particular quando a população associativa começou a decrescer (década de 1930), tinha que angariar sócios, justificar o aumento de cotas e concitar apoios, públicos e privados.

Raúl Esteves dos Santos, atendendo à forma como organiza a informação na diacronia, desde a fundação até ao "seu" presente - fundamentalmente, fim da década de 1930 -, atende a quatro períodos distintos na história da Sociedade.

O período fundador - 1879-1883: cingido à criação do jornal pelos Tabaqueiros e à superação da primeira crise de financiamento, com a constituição da Cooperativa, e da primeira luta com as outras classes profissionais, pelo controlo do jornal e da associação.

O segundo período - 1883-1890: corresponde à construção dos alicerces da futura Sociedade de Instrução e Beneficência A Voz do Operário. Após a descoberta do «elixir da longa vida» (Santos 1932 a, 27), com a decisão tomada pela associação de prestar auxílio aos sócios na realização dos funerais - medida que garantiu o rápido crescimento da população associativa ${ }^{6}$ - A Voz do Operário lançou-se no programa de criação de escolas para os seus associados.

O terceiro período - 1890-1924/25: balizado entre a publicação dos estatutos da Sociedade de Instrução e Beneficência e a intervenção da Comissão Administrativa e de Inquérito, nomeada pelo governador civil de Lisboa, este período corresponde à fase expansionista da associação, em sócios e em escolas, factos que a projetam socialmente, vendo-se legitimada pelos governos monárquicos e pelo Estado republicano, como também reconhecida por figuras políticas, por intelectuais, por professores e por publicistas atentos a experiências no campo da educação popular, quando não mesmo propulsores ou colaboradores em ações de educação do povo. Mas no após I Grande Guerra, a crise que a afeta a Sociedade, a braços com a dispendiosa construção da sede, minada por conflitos e tensões internas e mal gerida obriga à intervenção do governador de civil de Lisboa, que nomeia uma comissão para reorganizar a administração de A Voz do Operário.

\footnotetext{
${ }^{4}$ Uma lista cronológica referenciada vem publicada em Santos 1938, 97-99 e Brocas 1938, 34.

${ }^{5}$ Correspondem a títulos ou complementos de título de artigos ou monografias. $V d$. bibliografia final, com exceção de «A Voz do Operário - Grande Catedral do Bem», publicado na Revista Portuguesa de Comunicações, entre 1931 e 1935, textos que não se conseguiram localizar em nenhuma biblioteca pública.

${ }^{6}$ Num estudo sobre os fins das associações de socorros mútuos, como instrumentos de previdência social, salienta-se o facto de «o auxílio por morte dos sócios [constituir] um ideal constante» (Baptista 2016, 103), o que explica o êxito daquela concessão aos sócios de A Voz do Operário.
} 
O quarto período - 1926-1935: é a fase da reorganização da Sociedade, assinalada, a montante, pela revisão dos Estatutos e, a jusante, pela aprovação do Programa Pedagógico e Regulamento dos Serviços Escolares. Neste período assiste-se à emergência de uma nova geração nos corpos gerentes, à conclusão da construção da sede, com a mudança para as novas instalações, e à elaboração de propostas que reformem os diferentes serviços de $\mathrm{A}$ Voz do Operário, com destaque para os escolares.

É, sobretudo, sobre o período que se estende entre 1890 e 1935 que recai a investigação de maior fôlego sobre A Voz do Operário, interpretada no seu articulado fundamental - associativismo, educação e assistência - e pertencente a Ramiro Lopes (1995). Com uma investigação detalhada, centrada no jornal como fonte documental e apoiada no escrutínio de outras fontes impressas, produzidas pela e sobre a Sociedade, este autor salienta a importância da «Instrução» no programa da instituição e demonstra como o debate sobre a renovação/inovação pedagógica das escolas de A Voz do Operário foi sendo pontualmente retomado nas décadas de 1910-1920, sem que se tenha tomado uma posição, elaborado um plano ou adotado um modelo. A alfabetização do maior número de crianças e adultos, com recurso a contratos com escolas indiferenciadas para suprir as carências do Estado no apoio aos mais desfavorecidos, preponderou, como uma necessidade, sobre as críticas a «um ensino entendido como dogmático, livresco e metafísico», em oposição a «um ensino liberal, laico, positivo e racionalista». A ideia de um «modelo alternativo ao ensino oficial surge ocasional e disperso [...] sendo mais a expressão de um desejo, a afirmação de um ideal do que a proposição de um projeto consistente e sustentado» (Lopes 1995, 129). Esta situação altera-se a partir de 1924, período em que se começa a encarar de outra forma a reforma dos serviços escolares, processo que o autor analisa e com o qual conclui os capítulos dedicados à «Instrução» (Lopes 1995, 100-173). O presente artigo, no que respeita à reforma dos serviços escolares e ao processo de aprovação do Programa Pedagógico (1929-1935) é complementar da análise de Ramiro Lopes, embora se siga outra abordagem, possibilitada, em grande medida, pela utilização de outras fontes documentais, provenientes do arquivo da Sociedade ${ }^{7}$ e de arquivos pessoais de figuras ligadas à Voz do Operário ${ }^{8}$.

Ainda no capítulo do estudo da atividade propriamente escolar da Sociedade são de referir os artigos de Mesquita (1987) e Tavares \& Pimenta (1987, 363-374), alicerçados na análise de informações e de dados colhidos no jornal $A$ Voz do Operário. Ambos partem da questão das ligações entre educação e movimento operário durante a Primeira República e da indagação se o ensino na Voz do Operário se constituía como uma alternativa ao ensino oficial. O primeiro autor conclui que «A Voz com o seu modelo educativo não constituía uma alternativa ao oficial, mas o seu papel compensador [pelo número de escolas e de alunos] não deixa de ser digno de nota» (Mesquita, 385). Os segundos autores, que constatam o afastamento das escolas de A Voz de modelos alternativos, bem acolhidos pelas elites operárias, sindicais e libertárias, como o da Escola Oficina n. ${ }^{\circ} 1$ ou o das escolas racionais de Francisco Ferrer, concluem pelo «alinhamento com os programas oficiais» numa estratégia de promoção social dos associados (Tavares \& Pimenta 1987, 374).

Não existem muitos mais trabalhos sobre A Voz do Operário. Apesar de ser uma instituição omnipresente, sendo invariavelmente referenciada em artigos sobre associativismo, educação popular ou alfabetização ${ }^{9}$, arquitetura e urbanismo ${ }^{10}$ e ainda em iniciativas organizadas

\footnotetext{
${ }^{7}$ ANTT: fundo da Sociedade de Instrução e Beneficência A Voz do Operário (doravante SIBVO).

${ }^{8}$ Arquivo de História Social-ICS (doravante, AHS-ICS); BNP: Arquivo Histórico Social/Projeto MOSCA (doravante, AHS/Projeto MOSCA).

${ }^{9}$ A título de exemplo, refira-se: Candeias 2013; Melo 2008; Pintassilgo 2011, 2012.

${ }^{10}$ A emblemática sede da associação, projetada pelo arquiteto Norte Júnior em 1912, inscreveu a Voz do Operário nas histórias gerais da arte portuguesa do século XX e em abordagens temáticas mais específicas sobre arquitetura (Fernandes 1990; Galvão e Mendes 2011; Martín López 2014; Folgado 2016).
} 
de oposição ao regime do Estado Novo ${ }^{11}$, e de figurarem notícias em diversos dicionários temáticos ${ }^{12}$, o conhecimento sobre esta instituição não tem sido aprofundado. A maior carência de estudos situa-se sobre o período do Estado Novo. Para os anos recentes assinale-se o trabalho de Pascoal Paulus sobre a Escola da Ajuda, abrindo a porta ao período pós 25 Abril através do estudo da presença do Movimento da Escola Moderna nas escolas da Sociedade (Paulus 2013).

Por fim, cabe referir algumas edições da iniciativa de A Voz do Operário sobre a sua história, produzidas em contexto comemorativo (Santos 1983; Galhordas e Damas 1993). Com este sentido histórico e institucional, partiu também da Sociedade a promoção de uma monografia sobre a história da instituição, saída a público em 2018, da autoria de Alfredo Franco. É uma obra que cobre toda a história da instituição, desde a fundação do Jornal até a atualidade, incluindo os projetos de expansão para o futuro. Nela sistematiza-se a informação disponível nos trabalhos supracitados, contextualiza-se, na perspetiva política e social, as diferentes fases que pautaram a história da Sociedade e detalha-se, em notas, transcrições do jornal A Voz do Operário e apontamentos diversos, acontecimentos, iniciativas e figuras que marcaram a vida da Sociedade.

\section{A instituição (1890 - década de 1950)}

A Sociedade de Instrução e Beneficência A Voz do Operário nasceu imbricada em diversas iniciativas associativas dos operários da indústria dos Tabacos com o objetivo de defender a classe, na década de 1880, luta que se havia começado com a publicação de um jornal, em 1879. Todavia, aquela designação resulta dos estatutos aprovados em 1890, para justamente conferir à associação, já aberta à participação de outras classes profissionais, a vertente educativa e assistencial que os seus dirigentes e associados pretendiam desenvolver (Lopes 1995, 28-43). Na formulação estatutária, os objetivos da instituição eram enunciados de forma clara e sintética: manter o jornal A Voz do Operário; criar aulas diurnas e noturnas e gabinete de leitura; auxiliar os sócios e as suas famílias com a realização de funerais. Inaugurava-se então uma matriz de funcionamento que, apesar de ter conhecido transformações, na extensão e atualização de programas e de práticas, manteve-se nas suas linhas orientadoras ao longo do século XX.

Para ensaiar uma breve apresentação da instituição que contemple a sua evolução, tomese como referência cronológica as décadas de 1920-1930, com o sentido de evidenciar "um antes" e "um depois". Com efeito, aquelas décadas representam uma fase charneira na história da Sociedade, porquanto correspondem a um impulso renovador, tecido sobre a experiência anterior da associação (desde o fim do século XIX) e que ativou iniciativas que marcaram o seu âmbito de atuação posterior, que na presente análise se estende até à década de $1950^{13}$.

A Voz do Operário era uma grande instituição, administrada e suportada por trabalhadores pertencentes a diferentes classes profissionais. Também era para eles, associados e suas famílias, que se dirigiam todas as atividades desenvolvidas no seio da Sociedade. Esta constituía uma referência entre as hostes associativas da cidade de Lisboa e

${ }^{11}$ A Sociedade acolheu no seu Salão de Festas, por exemplo, reuniões e conferências públicas organizadas pelo Movimento de Unidade Democrática (MUD, 1945-1948) e comissão da candidatura de Norton de Matos (1949) e de Arlindo Vicente (1958) à Presidência da República. Para um repertório de imagens fotográficas, $v d$. FMS-Casa Comum: fundos Alberto Pedroso, Manuel Mendes e Mário Soares http://casacomum.org/cc/arquivos.

12 Por exemplo, sobre a Primeira República (Carvalho 2013), a história de Lisboa (Santana 1994) ou a memória urbana ligada a figuras e espaços de «libertários e afins» (Freire e Lousada 2013).

${ }^{13}$ Para esta síntese sumária complementaram-se os textos de Raúl Esteves dos Santos sobre a história de A Voz do Operário com pesquisa documental, recolhida em particular nas atas das sessões da comissão administrativa e da assembleia geral (para as décadas de 1920 a 1950) e nos relatórios anuais de atividades e contas da instituição (1935-1960). 
tinha a sua sede no populoso e popular bairro da Graça-São Vicente. Agregava uma vasta comunidade, composta por milhares de sócios ${ }^{14}$.

A Sociedade oferecia aos seus associados, desde o fim do século XIX, uma rede escolar de ensino primário, com escolas dispersas pela cidade, incluindo aulas noturnas para adultos. A rede compunha-se de quatro escolas privativas, organizadas pela Sociedade e com instalações e pessoal docente por si recrutado e remunerado. Uma delas, localizava-se na sede da associação - a primeira a ser inaugurada, em 1891. As demais escolas situavam-se em prédios alugados, estabelecidas nos anos imediatos (1892-1895). A este núcleo, estável, acrescentava-se um número variável de estabelecimentos escolares particulares com os quais a Sociedade realizava contratos para que, mediante um pagamento mensal, essas escolas recebessem alunos, filhos dos sócios, nas mesmas condições. Esta opção tomou-se a partir de 1895 para responder à explosão da procura. O número de escolas atingiu a centena em 1905, para se situar, no início da Primeira República, nas sete dezenas (Tavares \& Pimenta 1987). Os contratos firmavam-se e rescindiam-se, conforme a avaliação realizada pela comissão escolar da Sociedade sobre a qualidade das instalações e do ensino prestado por estes estabelecimentos particulares. E também em função da pertinência da localização, procurando-se bairros com grande concentração de operários. O número de escolas de contrato, de ensino diurno, apesar destas variações, tendeu a não ultrapassar as quatro dezenas entre as décadas de 1930 e $1950^{15}$. As aulas noturnas, circunscritas à escola da sede (privativa $n .{ }^{\circ} 1$ ), tiveram procura crescente e vêm a ser alargadas, neste mesmo período, a outras escolas privativas, porque, entendia a Sociedade, «valorizar trabalhadores» era a sua «missão principal» ${ }^{16}$.

A diversificação educativa, extensiva à população infantil (aula infantil) e feminina (curso de lavores e de modista) e englobando outros graus de ensino, como o profissional (curso comercial), começou a esboçar-se no fim da década de $1920^{17}$.

Igualmente a partir deste período, incorporaram-se gradualmente nos programas educativos outras práticas que pretendiam qualificar a educação, como sejam a observação e acompanhamento médico-pedagógico (médico escolar), ${ }^{18}$ a frequência de colónias de férias (a primeira realizou-se no Verão de 1938), as saídas em excursões escolares e visitas de

\footnotetext{
${ }^{14}$ A população associativa crescera de forma acelerada no fim do século XIX/primeira década do século XX, chegando aos 50 mil sócios, número que não parou de aumentar depois de 1910, situando-se em cerca de 70 mil associados (Tavares \& Pimenta 1987, 368). Com o findar da Primeira República inicia-se a tendência para o decréscimo, começando a ser um problema objeto de especial atenção dos corpos gerentes a partir de meados da década de 1930: 63514 sócios, em 1936; 52 683, em 1940; 48 962, em 1945; 40 092, em 1950; 33 814, em 1955; e 23 647, em 1965 (ANTT: Sociedade de Instrução e Beneficência A Voz do Operário, Relatório e Contas da gerência... para os anos referenciados e respeitando aos sócios existentes em 31 de Dezembro).

${ }^{15}$ Análise de dados estatísticos recolhidos em Relatório e Contas da gerência ... anos 1934/35 a 1960.

${ }^{16}$ Em 1930, o chefe dos Serviços Escolares, Adolfo Lima, refere-se à grande afluência de alunos no curso primário noturno (mais de 300) (SIBVO, Comissão Administrativa, ata 60, 18.06.1930, fl. 383). Sete anos depois, a escola privativa da Estrela (n. ${ }^{\circ}$ ) passa a dispor de cursos noturnos, que se estendem, em 1944, a mais dois estabelecimentos (privativas n. ${ }^{\circ}$ s 3 e 4) (Relatórios e contas... 1944, 14). A frequência sobe então para cerca de 600 alunos. Devido à imposição oficial da separação dos sexos (1937), as aulas para mulheres deixaram de funcionar na sede. Só em 1946 abrirá um curso na escola de contrato n. ${ }^{\circ}$ 22. A frequência não ultrapassava a meia centena. Em 1953, com o Plano de Educação Popular, decretado pelo Estado, e sequente campanha de alfabetização de adultos, a procura das aulas noturnas na Sociedade volta a crescer, com «centenas de alunos novos» (Relatório e contas...1946 a 1953).

17 Santos 1933b. A primeira aula infantil foi inaugurada na sede, junto da Escola Privativa n. ${ }^{\circ} 1$, em 12.02.1931 (ANTT: SIBVO, Livro de ocorrências...).

${ }^{18}$ Prática que se revelou de difícil aplicação a todas as escolas da Sociedade, e mesmo na da sede não funcionou regularmente nas décadas de 1930-1940 (AHS-ICS, Domingos da Cruz, «Retalhos para um livro de memórias que não escreverei (sofrimentos e saudades)», 1959, fl. 1-3. PT-AHS-ICS-PQ-CP-062-4.
} 
estudo, ${ }^{19}$ o ensino da educação física e a constituição de bibliotecas infantis, fixas e móveis (iniciadas em 1938). Esta experiência obteve grande sucesso e foi inteiramente financiada por um sócio benemérito, Fernando Rau. Em 1939, a Biblioteca Infantil tinha quatro salas de leitura, uma em cada escola privativa e nove bibliotecas circulantes, destinadas às escolas de contrato. Compunha-se de um fundo de 2000 volumes, escolhidos para as crianças, dispostos em estantes próprias. A dinamização educativa desta iniciativa incluía ainda lições, projeções, leitura de contos e seção de trabalhos manuais, acompanhados por professores ${ }^{20}$.

A dimensão educativa da Sociedade expandiu-se ainda por práticas dirigidas a adultos, no âmbito da formação intelectual, artística, social e cívica, organizadas segundo um programa com preocupações pedagógico-didáticas: encontravam-se neste caso as palestras e os programas de conferências, os espetáculos teatrais, os concertos e o cinema, embora não se excluísse o fator recreativo (exploração do Salão de Festas e da Esplanada, com programas mais descomprometidos ${ }^{21}$. Também com uma função educativa, fundou-se, em 1943, o Museu do Trabalho. Organizado em torno de fotografias e gráficos que mostravam o «calvário do Homem e a evolução progressiva das indústrias» (Santos 1948, 9), era apoiado por conferências sobre temas relacionados com o trabalho ${ }^{22}$.

Por fim, destaque-se a Biblioteca Social, com sala de leitura na sede e aberta ao público, e que a partir de 1943 passou a dispor de empréstimo domiciliário ${ }^{23}$. A biblioteca resultava do desenvolvimento crescente, embora arrítmico, de uma das primeiras iniciativas dos operários tabaqueiros em prol da educação do operariado, consubstanciada no gabinete de leitura (Franco 2018, 43). Os seus fundos eram alimentados por compra e por doações regulares, além das coleções ou bibliotecas que em diferentes momentos foram cedidas à associação por entidades cúmplices com o mundo operário, o associativismo e a educação popular, como, por exemplo, Boto Machado - deputado republicano e diplomata, que se bateu no parlamento pelo direitos sociais dos trabalhadores (Esteves 1936, 58-62) -, a Sociedade de Estudos Pedagógicos (19101035) - uma associação científica com especial atividade na reflexão e divulgação das novas correntes pedagógicas e empenhada na reforma da educação e ensino nacionais (Pintassilgo 2007, 2) - ou a Universidade Popular Portuguesa (1919-1950) - uma das mais relevantes e duradouras experiências dentro deste modelo de educação social, destinado "ao povo" e promovido pelas elites republicanas progressistas e operárias (Bandeira 1994) ${ }^{24}$.

No campo da assistência aos seus sócios, a Sociedade foi estendendo a rede de apoio: na morte, não deixou de ampliar os serviços funerários, iniciados, no fim do século XIX ${ }^{25}$. Preocupou-se com o berço, instituindo a distribuição de enxovais aos recém-nascidos em

\footnotetext{
${ }^{19}$ Realizavam-se, geralmente, no fim do ano escolar e não abarcavam os alunos de todas as escolas. Estas saídas conheceram uma organização regular no período em estudo e consistiam num programa de visitas a museus e património histórico (Relatório e contas...para os anos 1934-1965).

${ }^{20}$ ANTT: SIBVO, Relatórios e contas...1939, 16; Biblioteca Infantil, 1937-1939.

${ }^{21}$ A «Proposta para a utilização instrutiva do Salão», aprovada pela subcomissão de Instrução, Educação e Arte, em 1929 (AHS-ICS: PT-AHS-PQ-DOC-337), configurava um programa próprio de uma universidade popular, dentro do modelo da Universidade Popular Portuguesa (Bandeira 1994). Foi executada parcialmente.

${ }^{22}$ Reabriu várias vezes entre 1944 e 1948 e não se conseguiu desenvolver, mesmo com o auxílio dos «amigos da Sociedade», Fernando Rau e Diamantino Tojal (Relatório e contas..., 1944, 8). Desde a constituição do Museu era prática os operários enviarem os seus instrumentos de trabalho (SIBVO: Comissão Administrativa, ata 167, 14.11.1946, fl. 197).

${ }^{23}$ Em 1937, a biblioteca tinha um fundo composto por 12000 volumes e a sala de leitura registava um número anual de cerca de 5000 leitores (Brocas 1937, 28-33). O número de leitores tende a cair progressivamente e em 1946-1948 remodela-se a biblioteca e lança-se a ideia de organizar «serões mensais com leituras comentadas e recitativos» (Relatório e contas...1948, 9-10).

${ }^{24}$ Sobre estas duas últimas doações, vd. SIBVO, Assembleia Geral, ata 760, 10.12.1950, fl. 160-161.

${ }^{25}$ Do transporte numa carreta, em 1884, evoluiu-se para a concessão de subsídios por morte e depois para a constituição, em meados da década de 1920, de um serviço próprio ("agência" funerária) com possibilidade de garantir um funeral completo aos sócios e parentes.
} 
famílias desfavorecidas (1928) e contemplou os cuidados de saúde genéricos e especializados através da organização de uma policlínica (1926). Este apoio assistencial, abarcou ainda a atividade escolar, através do fornecimento de refeições (cantina escolar) ${ }^{26}$, distribuição de roupa, calçado e material escolar às crianças mais necessitadas, promoção das caixas escolares e ainda a concessão de bolsas de estudo a alunos que pretendessem prosseguir a sua formação escolar no ensino técnico ou no liceal. O auxílio pecuniário, sob a forma de prémios escolares entregues anualmente, foi também uma modalidade praticada ${ }^{27}$.

Enquanto instituição, sustentava-se com financiamento próprio - cotizações e receitas próprias -, mas a sua ação «instrutiva» e «beneficente» permitia-lhe captar outros recursos, quer através de apoios públicos, sob a forma de subsídios ocasionais, cedência de facilidades ou isenções, quer sob a forma de doações realizadas por empresas ou indivíduos e bem assim beneficiando de outras colaborações prestadas por intelectuais, professores, médicos, artistas, publicistas, comerciantes e empresários (criação de prémios para os alunos, prestação gratuita de serviços, que podia englobar o desenho de um projeto de um edifício, a construção de um pavilhão, a realização de um programa de conferências ou de um concerto, oferta de livros, de géneros alimentares e outros bens e equipamentos, por vezes sob a forma de legados testamentários) ${ }^{28}$. Dispunha ainda de um jornal mensal, distribuído gratuitamente aos sócios e composto e impresso em tipografia própria, que mantinha a comunidade informada sobre tudo o que respeitasse à associação, sobretudo à sua gestão e administração.

Uma associação desenhada dentro destes moldes, exigia uma organização estruturada de serviços - que se especializa e descentraliza com a reforma dos Estatutos, em 1926 assegurada pelos corpos gerentes, eleitos anualmente em assembleia geral, apoiados em comissões especializadas (as subcomissões de carácter permanente ou comissões de atuação conjuntural ou temporária) e por um quadro de funcionários remunerados, admitidos por concurso documental. Exigia também o fomento de uma teia de relações, quer com os poderes públicos quer com entidades coletivas e singulares. E também a gestão, dentro da Sociedade e entre os sócios, de sensibilidades e alinhamentos. Uns e outros relacionavam-se com a Sociedade por via de uma ação solidária, mas sob credos distintos. E é de admitir que esperavam contribuir para resultados também diferentes. Partindo desta possibilidade, poderse-á considerar existirem vários objetivos nesta participação social entendida como: uma modalidade de regulação social, visando a integração das massas populares na ordem social; uma estratégia de conciliação interclassista, com objetivos reformistas; ou uma estratégia de classe, procurando uma rutura com o sistema político estabelecido (Léon, 1983). «Une façon de faire la politique autrement» (Christen \& Besse 2017, 11-32).

Entre o fim do século XIX e o início de 1930, encontram-se neste campo de força, os grupos republicanos, maçons, libertários, sindicalistas ou socialistas, organizados em associações de diferente natureza. E entre eles existem estratégias de concorrência ou de

\footnotetext{
${ }^{26}$ A cantina escolar ficou confinada à escola da sede (1930). Só a partir de 1936, este tipo de assistência se começa a estender a outras escolas. Ainda assim, naquele ano, só em duas escolas privativas foram distribuídas 9 209 refeições (1. ${ }^{a}$ refeição) e 60550 (meio dia), sendo 12000 gratuitas (Relatórios e contas...1936, 23, 38-39 e ANTT: SIBVO, Relatório do Chefe dos Serviços Escolares, 1938, fl. 3-4).

${ }^{27}$ Em 1935, votou-se em assembleia geral a verba de $2000 \S 00$ anuais para subsidiar estudos secundários de alunos que tivessem concluído o ensino primário nas escolas da Sociedade (Relatórios e contas ... 1934-1935, 5). Nesse mesmo ano concederam-se subsídios a oito alunos. Também se atribuíam prémios escolares, instituídos com o mesmo fim por sócios beneméritos, como Ricardo Covões, empresário do Coliseu dos Recreios, a Liga Pró Moral, a Associação dos Antigos Alunos de A Voz do Operário, o Sindicato Nacional dos Construtores Civis, Herdeiros do construtor Diamantino Tojal, professores, etc., com valores nominais entre os $500 \$ 00$ e os 100\$00. Em 1947 estavam instituídos nove prémios, em 1960 ascendiam a 17 (Relatórios e contas...1947 e 1960). Isto não impedia apoios esporádicos da Sociedade como, em 1946, a determinação de conceder a um aluno, bolseiro desde o ensino primário, a quantia de $500 \$ 00$ para realizar os «preparatórios na Faculdade de Medicina» (SIBVO, Comissão administrativa, ata 168, 21.11.1946, fl. 198 vs).

${ }^{28}$ Baseado na análise dos relatórios de atividade e contas onde vêm listados as ofertas e os auxílios anuais.
} 
convergência, conforme o contexto político. Com a Ditadura Militar (1926-1933), seguida pela normalização institucional, decorrente da aprovação da constituição do Estado Novo (1933), a ação destes grupos políticos foi, naturalmente, cerceada. O movimento associativo conhece novas regras. Muitas associações encerram. Uma nova organização é estabelecida pelo Estado Novo. O contexto político e social altera-se. Ora é precisamente entre 1924 num contexto de declínio da Primeira República e de enfrentamentos sociais e políticos, que minam o movimento associativo e as organizações operárias, e 1932 - ano em que na Ditadura Militar estão já definidas as suas orientações políticas e fixado o quadro normativo de que resultará a constituição de um sistema político autoritário e corporativo - que a Sociedade de Instrução e Beneficência A Voz do Operário intenta levantar um projeto educativo, que ultrapassa a prática que tinha sido sua - escolarização, com apoio social limitado, e educação social, por via do fomento da leitura (jornal e biblioteca) e da conferência -, para se fixar num programa mais vasto de educação da classe trabalhadora onde, julga-se, se pode ler uma outra estratégia sociopolítica que merece ser investigada.

\section{A reforma dos serviços escolares, 1924/25 - 1935}

O grande empreendimento da Sociedade, desde o início do século XX, vinha sendo a construção da sua sede. A ambição do projeto, concretizado num edifício monumental e de grandes dimensões, à qual se juntou a crise económica e social decorrente da guerra, fez arrastar as obras, avolumar as despesas e crescer o descontentamento entre os associados. A construção da sede «considerada pelos mais prudentes como uma loucura» (Santos 1944, 4), era vista pelos mais críticos como resultado de uma decisão leviana, que obrigou a «sacrificar os serviços de instrução e outros objetivos da Sociedade» ${ }^{29}$. Só no fim do ano de 1923, os serviços da Sociedade mudaram para as novas instalações, mas o edifício não estava terminado e só o puderam ocupar parcialmente e em condições adversas. As salas de aulas tinham 80 alunos, a cerca de recreio estava por terraplanar, não podendo ser utilizada pelas crianças, os terraços, localizados nos pavimentos superiores, não tinham ainda guarda de proteção, colocando em risco os alunos, entre outros problemas que afetavam a segurança e a funcionalidade do edifício ${ }^{30}$. Acrescia que os corpos gerentes enfrentavam reclamações salariais dos funcionários da Sociedade, tendo-se mesmo nomeado uma comissão de sócios auxiliares para estudar o problema, e desde 1919 que as comissões administrativas não apresentavam os relatórios de atividades e contas de gerência à assembleia geral para aprovação ${ }^{31}$. Neste contexto, o governador civil de Lisboa suspendeu os corpos gerentes eleitos e nomeou uma Comissão Administrativa e de Inquérito, designada na documentação por Comissão de Sindicância, com a dupla função de reorganizar a administração da Sociedade e de sindicar a instituição, contando com a intervenção das autoridades policiais.

\section{A comissão de sindicância, 1924-1925}

A comissão era composta por um presidente, o representante do governador civil, e sete vogais - sócios da Sociedade -, a quem foram distribuídos pelouros próprios: a Domingos da Cruz atribuiu-se os assuntos da instrução e a José Maria Gonçalves, os da administração geral ${ }^{32}$. A comissão entrou em exercício em 15.07.1924 e concluiu os seus trabalhos em 3.01.1925 $5^{33}$.

\footnotetext{
${ }^{29}$ ANTT: SIBVO: Comissão Administrativa, ata n. ${ }^{\circ}$ 7, 07.08.1924, fl. 42.

${ }^{30}$ Idem, ata n. ${ }^{\circ}$ 9, 21.08.1924, fl. 50-51.

${ }^{31}$ Idem, Assembleia Geral, ata de 24.04.1924, fl.182.

${ }^{32}$ ANTT: SIBVO, Comissão Administrativa, ata de entrega de valores, 15.07.1924, fl. 22-23.

${ }^{33}$ Idem, ata n. ${ }^{\circ} 1,15.07 .1924$ a n. $^{\circ} 33,3.01 .1925$, fl. 22-134.
} 
Como Domingos da Cruz recordará mais tarde, "[teve-se] de refundir, de alto a baixo toda a vida e atividades da Sociedade, sobretudo as educativas ${ }^{34}$. Mas o trabalho que desenvolveu, em concordância com José Maria Gonçalves, sendo todas as propostas aprovadas pela comissão, tinha subjacente uma orientação pedagógica nova, com o intuito de definir os «objetivos educadores e instrutivos [para] a coletividade» e combater o «desordenado automatismo» instalado nas escolas e em todo o funcionamento dos serviços escolares $^{35}$. Em poucos meses, Domingos da Cruz gizou um plano de conclusão das obras com o arquiteto, propôs alterações na ocupação do espaço, para racionalizar os serviços, e conseguiu obter um empréstimo bancário, depois do pedido ser autorizado pelo governador civil, para prosseguir as obras. No capítulo pedagógico, investiu sobretudo em métodos de registo e observação dos alunos, desde o estabelecimento da estatística escolar (frequência e aproveitamento, controlo dos materiais distribuídos) até à inspeção médico-escolar (que englobava a antropometria, o exame clínico, o despiste de doenças e anomalias, as necessidades especiais e a avaliação sociofamiliar) com o objetivo de melhor adaptar a criança ao ensino. O preenchimento destas fichas, que configuravam um boletim individual do aluno, resultaria de uma observação coordenada e realizada pelo médico, com a contribuição dos professores e da família.

Domingos da Cruz tomou ainda muitas outras medidas, de forma a pôr em funcionamento as escolas da Sociedade, desde recrutar professores, desdobrar aulas, disciplinar práticas docentes, nomeadamente nas escolas de contrato, e controlar a observância da orientação pedagógica, através de uma inspeção regular, para a qual nomeou um professor. Por fim, investiu em novas modalidades educativas, que se acrescentavam aos programas curriculares com igual importância: organização de excursões escolares; estabelecimento de caixas escolares, geridas pelos alunos; constituição de um museu escolar; adoção de canções e jogos infantis na prática escolar, com uma seleção já realizada e aprovada para ser distribuída aos professores. De sublinhar, que nas instruções aos docentes emitidas por Domingos da Cruz, todas estas atividades se justificavam por no seu conjunto promoverem a educação física, intelectual e moral, social e cívica, além de fortalecerem o carácter, o sentimento do dever e da solidariedade. E ainda criou mecanismos para que este programa se estendesse a todas as escolas, privativas e de contrato, da Sociedade ${ }^{36}$.

\section{A normalização após a sindicância: reequilíbrios de poder e nova orgânica administrativa}

Duas grandes questões levantadas pela Comissão de Sindicância relativamente à gestão da Sociedade, para as quais se impunha uma solução, perdurariam nos debates que absorviam os associados nas assembleias gerais dos anos de 1925-1926: a contestação da supremacia dos tabaqueiros na administração da Sociedade, consagrada estatutariamente e que limitava a participação de outros grupos ou classes profissionais; e o descuido com a instrução e a beneficência, visto como uma abdicação dos desígnios fundadores da associação. Estas questões debatiam-se num ambiente associativo muito fraturado.

\footnotetext{
${ }^{34}$ AHS-ICS: Domingos da Cruz, «Retalhos para um livro de memórias...», 1959, fl. 11. Vd. biografia deste dirigente na p. 204 do presente texto.

35 AHS-ICS: «Sociedade de Instrução e Beneficência A Voz do Operário, Ordem de serviço n. ${ }^{\circ} 33$ », 10.11.1924, PT-AHS-ICS-PQ-DOC-359.

${ }^{36} \mathrm{O}$ relatório elaborado por esta comissão só foi entregue ao governador civil, facto que motivou protestos na Sociedade. Tentou-se localizar o referido relatório no arquivo do Governo Civil de Lisboa, mas sem sucesso.
} 
Não se pode ignorar os níveis de participação e representação associativas. Apenas um grupo relativamente circunscrito, constituído pelos sócios mais militantes pela causa do associativismo, acorria às reuniões. Raramente ultrapassavam as cinco dezenas de sócios, entre efetivos e auxiliares (e estes últimos intervinham, mas não tinham direito de voto), e apenas nos atos eleitorais as presenças rondavam a centena. E mesmo esta afluência já era generosa para o padrão mais corrente. Numa das assembleias gerais, em que estavam presentes apenas 30 sócios, observava-se sobre a cronicidade da situação: «as coisas continuam a ser o que sempre têm sido: uma questão de lana caprina é capaz de encher uma casa, para dirimir questões de princípio, não aparece ninguém» ${ }^{37}$. E para os mais críticos por esta falta de participação, não havia mesmo número de sócios para a assembleia funcionar senão «cheirava a escândalo» ${ }^{38}$.

Os confrontos ideológicos, as desconfianças políticas e as disputas de poder que se detetam na leitura das atas da assembleia geral nunca são discutidos explicitamente, mantêmse em estado de latência e emergem de comentários laterais, mas significativos. Por exemplo, numa sessão refere-se que «a comissão de dirigentes da Voz do Operário que procurou António Maria da Silva (1872-1950) ${ }^{39}$ lhe disse que a Confederação Geral do Trabalho [de orientação anarquista] se queria apoderar da Voz para dentro dela fazer propaganda perniciosa $»^{40}$. Em outra sessão acusam-se os tabaqueiros de pretenderem fazer da Sociedade um «baluarte socialista» ${ }^{41}$. A prudência em se apoiar O Socorro Vermelho ${ }^{42}$, sem primeiro se conhecer bem os fins da organização, suscitou o reparo crítico de um sócio sobre o «medo» que reinava na Sociedade a tudo o que era «vermelho» ${ }^{43}$. E já antes deste evento se havia reagido com grande determinação às notícias publicadas num jornal católico, onde se referia que nas escolas da Voz do Operário se recrutavam crianças para a Legião Vermelha ${ }^{44}$. A Associação do Pessoal dos Tabacos manifestou logo com veemência o seu protesto e pela administração da Sociedade decidiu-se enviar a todas as «associações liberais do país» uma nota impressa com um desmentido, para se contornar os efeitos da censura à imprensa que já tinha sancionado um artigo de A Batalha - o órgão da Confederação Geral do Trabalho - pelo qual se denunciava a falsidade da informação ${ }^{45}$.

Destes exemplos, entre muitos outros que ficam por referir, retira-se uma ideia essencial: os tabaqueiros, de influência socialista, pretendiam assegurar o controlo político da Sociedade, e para isso havia que limitar as possibilidades de intervenção de grupos anarquistas, corrente dominante no movimento operário, e afastar as contaminações bolchevistas (o Partido Comunista Português fora fundado em 1921). De certa forma, replicava-se a luta entre os socialistas e os anarquistas no movimento sindical, quando a influência dos primeiros se viu atacada, em 1909, e desalojada, em 1917/1919, pelos

${ }^{37}$ ANTT: SIBVO, Assembleia Geral, ata n. ${ }^{\circ}$ 427, 12.11.1925, fl. 106.

${ }^{38}$ AHS-ICS: Domingos da Cruz, «Retalhos para um livro de memórias...», 1959, fl. 14.

39 Político republicano, destacado membro da Maçonaria e figura preponderante do Partido Republicano (Democrático). Foi várias vezes ministro e presidente do governo durante a Primeira República.

${ }^{40}$ ANTT: SIBVO, Assembleia Geral, ata n. ${ }^{\circ} 390,25.02 .1924$, fl. 177.

${ }^{41}$ Idem, ata n. ${ }^{\circ} 425,7.10 .1925$, fl. 89.

${ }^{42}$ Recém organizado, pretendia apoiar as famílias dos primeiros deportados políticos, vítimas da repressão que começou a atingir duramente as organizações republicanas, anarquistas, comunistas e operárias. A primeira grande deportação ocorre na sequência da revolta militar de 3-7 de fevereiro de 1927 contra a Ditadura Militar, que teve a participação civil de algumas daquelas organizações.

${ }^{43}$ ANTT: SIBVO, Assembleia Geral, ata n. ${ }^{\circ}$ 483, 16.09.1927, fl. 350.

44 Organização clandestina radical, criada em 1919 e praticamente desmantelada em 1925, após ter organizado o atentado ao comandante da Polícia, Ferreira do Amaral. Atribui-se-lhe vários atentados bombistas.

${ }^{45}$ Idem, ata n. ${ }^{\circ} 464,26.08 .1926$, fl. 267-268. 
anarquistas (Freire 1992, 193-197; Pereira 2009, 421-440). Neste difícil equilíbrio, os representantes dos tabaqueiros não se escusaram a desenvolver estratégias de aproximação com os republicanos, inclusive com os seus governos. E podemos concluir que na gestão da questão social, este controlo de forças era favorável à política dos governos republicanos, fosse ela de tendência mais conservadora ou mais progressista. Mas a abertura da Sociedade à participação de outras classes e grupos, admitindo a passagem de sócios auxiliares (todos os que não pertenciam à indústria dos Tabacos) a sócios efetivos (os únicos que podiam votar e ser eleitos, sendo do sexo masculino e maiores de idade), não só acalmava a turbulência na associação e garantia a sua sustentabilidade, nomeadamente pela necessidade de ampliar e renovar os seus quadros dirigentes, como permitia a participação mais ativa de grupos reformistas afetos ao republicanismo. Leia-se, capazes de contribuírem para a integração das massas trabalhadores, seduzidas por propostas políticas mais radicais, na organização política e social republicana. Esta é uma leitura possível se atendermos à forma como a questão do estatuto dos sócios auxiliares encontrou o seu desfecho.

As reivindicações dos sócios auxiliares eram anteriores à intervenção da Comissão de Sindicância. E esta, no relatório entregue ao governador civil de Lisboa, propunha que se terminasse com «o estranho privilégio» dos tabaqueiros, «tornando votantes e elegíveis os muitos milhares de sócios auxiliares contra escassas centenas» pertencentes à indústria dos Tabacos $^{46}$. Esta alteração foi, na prática, imposta aos tabaqueiros e exigiu um compromisso que obrigou à intervenção do ministro do Trabalho. Este chamou ao seu gabinete o presidente da assembleia geral porque «se via apoquentado, por uns e por outros» e pretendia saber se os tabaqueiros se mantinham intransigentes. Reafirmou a necessidade de se admitir o maior número possível de sócios com direito a voto e apelou a um consenso: «os senhores resolvem, eles [os sócios auxiliares] transigem, que mais querem?». A resposta dos dirigentes foi clara: pretendiam resolver a questão, mas sobrava uma dúvida - «a classe operária está dividida em grupos que aqui dentro amanhã se poderiam digladiar ${ }^{47}$. As listas de promoção dos auxiliares a efetivos eram elaboradas com cálculo político ${ }^{48}$, abrangiam um número reduzido de elementos e não satisfaziam nem aos sócios auxiliares nem ao ministro. Surgiram depois as propostas por antiguidade. E foi o ministro que arbitrou a solução final: os sócios auxiliares adquiriam a categoria de efetivos quando completassem quinze anos de associados ${ }^{49}$.

Esta alteração foi importante para a renovação dos dirigentes associativos. E se abria a possibilidade à manifestação de influências mais radicais que o socialismo ordeiro dos Tabaqueiros, também permitia acolher iniciativas de figuras do republicanismo, com uma visão reformista e interclassista.

Os novos direitos dos sócios obrigaram à redação de um novo estatuto e regulamento geral interno. Mas outras alterações foram introduzidas, nomeadamente as relacionadas com a orgânica administrativa, assim como se regulamentavam novas iniciativas, a maioria ligadas ao programa educativo. Refira-se, em traços muito sintéticos, as alterações introduzidas na administração dos Serviços de Instrução, Educação e Arte $\left(v d\right.$. diagrama) ${ }^{50}$.

\footnotetext{
${ }^{46}$ AHS-ICS: Domingos da Cruz, «Retalhos para um livro de memórias...», 1959, fl. 11.

${ }^{47}$ ANTT: SIBVO, Assembleia Geral, ata n. ${ }^{\circ} 426,15.10 .1925$, fl. 91-92.

${ }^{48}$ Um dos nomes propostos era o de Ramada Curto (1886-1961) (Assembleia Geral, ata n. ${ }^{\circ} 426 \ldots$, fl. 90), advogado, deputado e uma das figuras de referência do Partido Socialista na Primeira República.

${ }^{49} \mathrm{Idem}$, ata $\mathrm{n}^{\circ}$ 427, 12.11.1925, fl. 110.

${ }^{50}$ Estatutos aprovados em Assembleia Geral de 25.11.1925, procedendo-se em seguida à elaboração do regulamento, discutido e aprovado no primeiro semestre de 1926 (ANTT: SIBVO, Assembleia Geral, atas n. ${ }^{\circ}$ 438 a 461, 12.03.1926-3.06.1926, fls. 173-245; Sociedade de Instrução...1926, 1931).
} 
Os corpos gerentes - mesa da assembleia geral, comissão administrativa e conselho fiscal - eleitos anualmente, mantinham a mesma composição, mas viam-se reforçados por órgãos auxiliares especializados. O pelouro da Instrução, Educação e Arte cabia ao 2. ${ }^{\circ}$ secretário da comissão administrativa (doravante, $\mathrm{CA})^{51}$ e a subcomissão, com a mesma designação, encontrava-se sob a sua presidência. À subcomissão, composta por oito membros, recrutados entre os sócios efetivos e auxiliares e aprovada anualmente em assembleia geral (doravante AG), sob proposta da CA, competia-lhe: estudar a orientação a imprimir ao ensino; estabelecer contacto com «ilustres» pedagogos, para reformar «lenta e progressivamente os métodos de ensino», incluindo criação de novas escolas, segundo processos pedagógicos modernos e tendo em vista, principalmente, o ensino profissional, que tornasse o aluno apto a enfrentar a vida; ${ }^{52}$ estudar, propor ou promover múltiplas atividades complementares ao ensino (festas, palestras, visitas escolares a museus, fábricas e oficinas, excursões recreativas e caixas escolares) ou de âmbito cultural (exposições, concertos musicais, conferências, exposições e festas artísticas e culturais destinadas a educar o gosto dos sócios e suas famílias).

\section{ADMINISTRAÇÃO DOS SERVIÇOS DE INSTRUÇÃO, EDUCAÇÃO E ATRTE NA ORGÂNICA DA SOCIEDADE \\ Diagrama baseado no regulamento interno, de junho de 1926, alterado em maio de 1929}

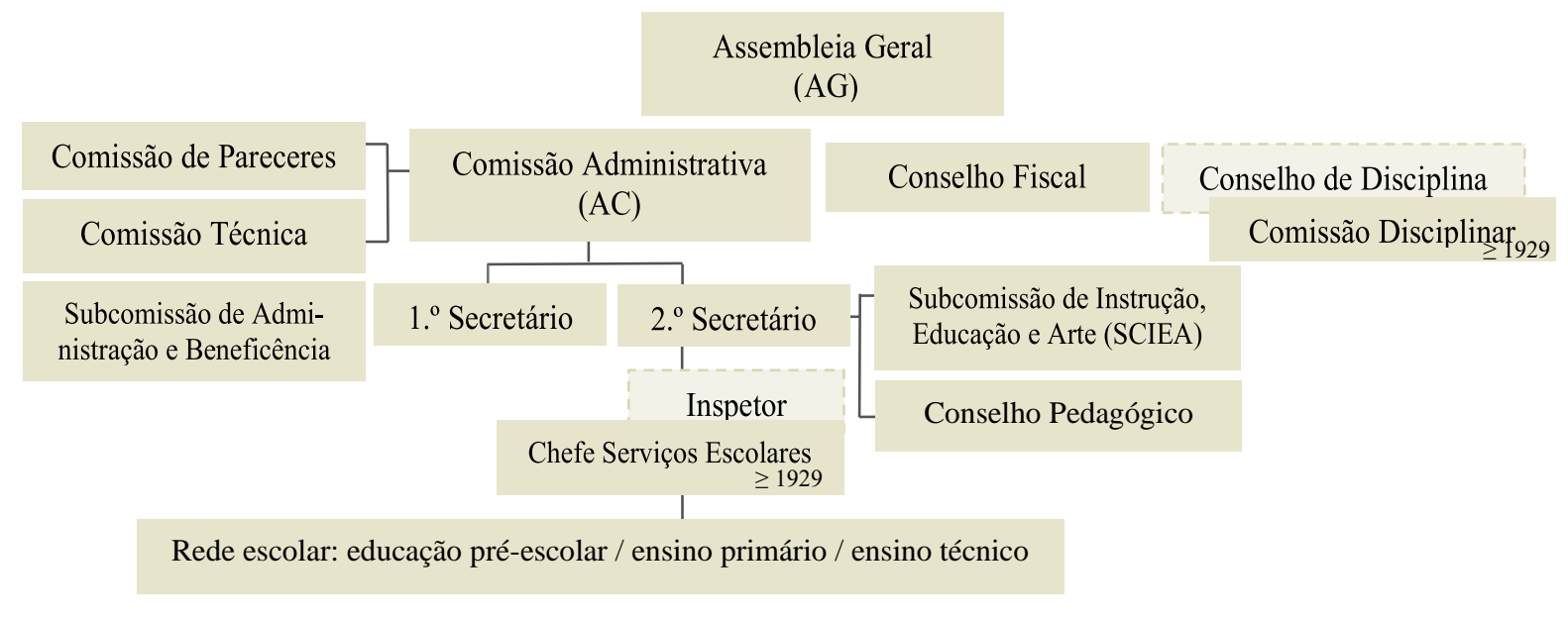

Com funções fiscalizadoras surgia o cargo de inspetor escolar, em contato permanente com todas as escolas da Sociedade, para melhor se conferir unidade ao ensino, acompanhando com regularidade a prática escolar, organizando a administração em toda a rede de escolas, privativas e de contrato, devendo ainda elaborar um relatório mensal, para conhecimento do 2. ${ }^{\circ}$ secretário, a quem respondia pela sua atividade. $O$ inspetor assistia às reuniões da subcomissão. Este cargo era provido por concurso documental e exigia-se ao candidato diploma das escolas normais (as escolas que formavam os professores primários) ${ }^{53}$.

Esta estrutura completava-se com um conselho pedagógico, órgão consultivo, também presidido pelo 2. ${ }^{\circ}$ secretário e composto por professores (três diretores das escolas privativas e por quatro professores privativos e de contrato) eleitos pelo corpo docente de todas as escolas da Voz do Operário. As reuniões, além da realizada obrigatoriamente no início do ano letivo,

\footnotetext{
${ }^{51}$ A CA compunha-se de sete membros: presidente, dois secretários, dois tesoureiros e dois vogais. O $1 .^{\circ}$ secretário tinha o pelouro da administração e beneficência (Sociedade Instrução...1926, artigo 31. ${ }^{\circ}$ dos Estatutos).

52 Sociedade de Instrução...1926, artigo $137 .^{\circ}$ do Regulamento.

${ }^{53}$ Idem, artigos $294 .^{\circ}-295 .^{\circ}$ do Regulamento.
} 
efetuavam-se quando fossem convocadas pelo presidente ou por dois terços dos professores. Competia ao conselho pedagógico intervir na elaboração de horários, na escolha de materiais escolares, na programação de festas e excursões e ainda dar pareceres por solicitação da CA ou do inspetor e propor modificações e iniciativas educativas ${ }^{54}$.

Os novos órgãos e cargos tinham assim funções de estudo e fiscalização, destinavamse a melhorar a eficiência administrativa e a incorporar competências especializadas. Os serviços de Instrução, Educação e Arte contavam ainda com duas comissões que assistiam todos os departamentos administrativos da Sociedade: a de pareceres, constituía o último filtro avaliador de qualquer proposta sujeita a apreciação da AG; e a técnica, que agregava sócios com formação em engenharia, arquitetura e construção civil, incluindo operários destas especialidades, colocava à disposição da Sociedade aconselhamento nas obras a realizar nas suas instalações e nos edifícios escolares, existentes ou a construir ${ }^{55}$. Em 1929, o Regulamento Geral da Sociedade conhece alterações. O cargo de inspetor passa a designar-se chefe dos Serviços Escolares e, embora tenha atribuições idênticas, valoriza-se a sua ação como «superintendente» dos serviços e atribui-se-lhe explicitamente, a organização e a responsabilidade da seção escolar ${ }^{56}$.

Resta salientar que as subcomissões, que eram aprovadas anualmente em AG sob proposta da CA, podiam não ser constituídas se a comissão não o julgasse necessário ${ }^{57}$. Também o chefe dos Serviços Escolares, caso o cargo não estivesse provido, podia ser nomeado pela CA, dispensando-se concurso. A escolha poderia recair num professor da Sociedade ou numa figura estranha à Voz do Operário, desde que fosse «comprovadamente competente em assuntos pedagógicos» ${ }^{58}$. Estas condições conferiam à CA a maleabilidade suficiente para afirmar posições e aliviar pressões, permitindo uma gestão mais direta em tempos de impasse, de crise ou de controvérsia ${ }^{59}$.

Foi com esta reestruturação orgânica que a instituição se preparou para empreender a reforma dos serviços escolares.

\section{Programas e regulamentos - 1929, 1932, 1935}

A primeira CA eleita no contexto pós Sindicância - a gerência de 1925/26 - elaborou um plano de ação com medidas para melhorar o ensino primário, desenvolver a assistência escolar, introduzir cursos profissionais, estruturar atividades para a formação sociocultural dos associados e expandir os serviços de assistência aos sócios (sanitários, materno-infantis, cuidados de saúde) (Esteves 1933b, 9-10) ${ }^{60}$. O plano continha linhas de orientação que seriam seguidas nas gerências de 1926/27 a 1928/29 - já constituídas ao abrigo dos Estatutos de 1926 -, mas com outras ambições e que produziram resultados: em 1929 era aprovado o Programa Pedagógico, seguido da elaboração de um regulamento para os Serviços Escolares. Com estes instrumentos normativos tentava-se transformar o ensino das escolas já existentes da Voz do Operário, como ainda estabelecer um novo programa educativo, muito mais abrangente. Obedecia a um modelo educativo. Embora se respeitassem os programas oficiais, o programa conjugava as propostas das novas correntes pedagógicas com as necessidades da população associativa a que se destinava. E comportava objetivos que transcendiam assegurar a mera

\footnotetext{
${ }^{54}$ Idem, artigos $331 .^{\circ}$ a $336 .^{\circ}$ do Regulamento.

${ }^{55}$ Idem, artigos $138 .^{\circ}, 141 .^{\circ}-142 .^{\circ}$ do Regulamento.

${ }^{56}$ Sociedade de Instrução... 1931, artigos $296 .^{\circ}$ e $299 .^{\circ}$ do Regulamento.

${ }^{57}$ Sociedade de Instrução...1926, artigos $134^{\circ}-135^{\circ}$ do Regulamento e $34 .^{\circ}, 10 .^{\circ}$ dos Estatutos.

${ }^{58}$ Idem, artigo $297 .{ }^{\circ}$ do Regulamento.

${ }^{59}$ Como aconteceu em 1930, 1933 e 1934, com as demissões sucessivas dos chefes dos serviços escolares, e em 1930/31, 1937 e 1940, anos marcados por crises de poder internas, não se tendo nomeado as subcomissões.

${ }^{60} \mathrm{O}$ plano pertence a Esteves dos Santos, feito por solicitação do presidente da CA, o tabaqueiro José Maria de Barros. Até esta data não se lhe conhece participação ativa na vida da Sociedade.
} 
instrução primária e a promoção de uma "ideologia" associativa através do jornal da Sociedade ou de rituais identitários, como até então tinha sido regra ${ }^{61}$.

Pelo Programa Pedagógico, organizado em 16 bases (Sociedade...1935), definia-se que a assistência a prestar às crianças da Voz do Operário tinha um tríplice objetivo, «instrutivo, educativo e social» (Base 1. ${ }^{a}$ ). Aquela iniciava-se com uma formação geral (bases 2. ${ }^{\mathrm{a}}$ a $6{ }^{\mathrm{a}}$ ), constituída pelo ensino primário, de acentuado cunho prático (trabalhos manuais e modelação) e baseado na observação, registo e acompanhamento médicos. A promoção da saúde dos alunos surge como uma componente essencial e a observação regular e metódica a sua condição essencial. De uma classificação assim realizada pelo médico escolar dependia a distribuição dos alunos pelas classes de ginástica, a concessão gratuita de refeições aos mais necessitados, completada com assistência medicamentosa reconstituinte e conselhos à família sobre o regime a seguir (incluindo vestuário e dieta alimentar). Esta preocupação sanitária estendia-se às instalações escolares, que deveriam estar em edifícios apropriados, e ao seu mobiliário, pedagogicamente adequado. Se as excursões escolares beneficiavam a saúde dos alunos, junto com o teatro, o canto e o orfeão contribuíam também para a educação do carácter e para a promoção da cultura artística.

À formação geral, seguia-se a especial (bases 7. a 14. ${ }^{a}$ ), de molde a assegurar-se uma educação integral. Deveria por isso iniciar-se o estudo da criação de escolas profissionais, com cursos teóricos e práticos, a englobar o curso comercial elementar e diversas oficinas. Admitia-se, no futuro, chegar à constituição de uma universidade popular técnica, nos graus médio e superior (industrial e comercial), sendo de prever, no plano futuro de construções, a inclusão de um internato e de um semi-internato. A educação nos princípios associativos e cooperativistas intersectava todo o programa, e era realizada através das associações escolares, administradas pelos alunos, e das cooperativas de produção e consumo, organizadas a partir das oficinas constituídas para aprendizagem prática dos cursos profissionais.

Com este modelo educativo, a Sociedade pretendia «preparar os alunos para a vida», assumindo a sua proteção, que começava na saúde e se concluía com a colocação no mercado de trabalho. Mas ainda aqui, não abandonava o aluno. Acompanhava-o na sua evolução, quer no meio social quer na sua vida particular. Porque só desta forma se poderia avaliar a função social da Coletividade «como grande conglomerado que é e como realizadora de uma alta função construtiva na sociedade portuguesa» (Base 10. ${ }^{\mathrm{a}}$ ).

$\mathrm{Na}$ administração da Sociedade que promoveu a elaboração do Programa Pedagógico e conseguiu a sua aprovação, destacou-se José Gregório de Almeida (1883-1954), presidente da CA, reeleito sucessivamente. Era um guarda-livros, sindicalista ativo e deputado socialista $^{62}$. Pouco antes de iniciar a sua primeira gerência, e no rescaldo dos conflitos internos, havia proclamado numa sessão da assembleia geral: «Estamos cumprindo uma alta missão social, façamos obra que assuste a burguesia» ${ }^{63}$.

Na subcomissão de Instrução, Educação e Arte (doravante SCIEA), nomeada por estas gerências ${ }^{64}$, destacamos, pela presença em dois ou mais anos: João Camoesas (1887-1951), médico e político, deputado pelo Partido Republicano (1915-1926), ministro da Instrução pública (1923 e 1925); Manuel da Silva, professor primário na Casa Pia, sindicalista e simpatizante anarquista, membro das mais importantes associações de professores, como a União dos Professores Primários e a Associação dos Professores de Portugal; Amílcar Costa,

\footnotetext{
${ }^{61}$ Sobre a importância das celebrações dos aniversários desde a fundação da Sociedade, vd. Lopes 78-96. Estas celebrações, que incluíam marchas com bandas filarmónicas, conferências, espetáculos e desfiles, mantiveram-se nas décadas de 1930 e 1940, e em alguns anos com redobrado investimento e visibilidade pública.

${ }^{62}$ Representou o Sindicato dos Caixeiros de Lisboa no Congresso Operário de 1925 (Freire 2012) e foi deputado, entre 1919-1921, pela minoria socialista que entrou no Parlamento com o concurso do Partido Republicano.

${ }^{63}$ ANTT: SIBVO, Assembleia Geral, ata n. ${ }^{\circ}$ 454, 20.05.1926, fl. 260.

${ }^{64}$ Os elementos biográficos que não estejam referenciados, coligiram-se em Freire 2012 e Nóvoa 2003.
} 
empregado no comércio, republicano; Alexandre Vieira (1888-1973), compositor tipográfico, sindicalista revolucionário, um dos mais prestigiados líderes sindicais da Primeira República; Maria O'Neill (1873-1932), autora de livros infantis, envolvida no movimento de defesa da criança, da mulher e da escola. E em 1928, entram Domingos da Cruz (1880-1963), 1. ${ }^{\circ}$ tenente da Marinha, republicano, deputado pelo Partido Republicano (1915-1921), e Augusto Carlos Rodrigues, guarda-livros, anarquista.

Trata-se de um grupo muito ativo política e socialmente, seja no parlamento ou nas associações sindicais. E todos participam do movimento de educação popular, sendo sócios de diversas instituições, integrando as suas direções ou o elenco de conferencistas. E escrevem na imprensa associativa, geralmente sobre assuntos da educação. Têm uma cultura pedagógica, estão a par das mais recentes experiências feitas em Portugal ou no estrangeiro, e, embora com filiações políticas distintas, estão empenhados em melhorar a situação das classes trabalhadoras.

Domingos da Cruz, por exemplo, era sócio de várias associações, como a Escola Oficina n. ${ }^{\circ}$ 1, o Asilo de São João e o Centro Boto Machado, todas ligadas à Maçonaria, organização de que fazia parte. Também aderiu à Universidade Popular Portuguesa, onde Alexandre Vieira e Augusto Carlos Rodrigues tinham uma participação muito ativa, aproximando o movimento operário e os setores anarquistas dos republicanos críticos e reformistas, representados pelo Grupo Seara Nova (Bandeira 1994). Além da carreira na Armada, onde começou por ser enfermeiro, D. Cruz fez um percurso político, como deputado e chefe de Gabinete dos ministros do Trabalho e das Colónias (1919-1923). Foi ainda nomeado para comissões de serviço público sobre assuntos do trabalho. Na Câmara dos Deputados, em 1917, a propósito de um projeto-lei sobre o inquilinato, pede intransigência no cumprimento da lei que tenta proteger as classes pobres da especulação dos senhorios: «O povo quer obras, quer que a República corresponda aquilo que dela muito legitimamente espera.» E se não for este o rumo, adverte que se «contraem dívidas que cedo ou tarde se terão de pagar» ${ }^{65}$. Mas também considerava que as reivindicações do movimento operário, apesar de justas, continham exageros que, a manterem-se, acabariam por «mata[r] a República e talvez promover um grande retrocesso na Democracia ${ }^{66}$. Era um reformista: manteve sempre contatos com a elite sindicalista e anarquista, tendo relações próximas com Alexandre Vieira, Emílio Costa, Campos Lima e Pinto Quartin, estes três últimos, intelectuais e doutrinadores do anarquismo em Portugal ${ }^{67}$. Domingos da Cruz, participara na Sindicância à Voz do Operário, em 1924. Volta, quatro anos depois, para terminar a renovação pedagógica que iniciara. O Programa Pedagógico pertence-lhe por inteiro. E para o aplicar, por sua sugestão foi nomeado Adolfo Lima (1874-1943), como chefe dos Serviços Escolares. E foi este pedagogo que elaborou o regulamento dos serviços.

Lima era um dos responsáveis pela difusão do movimento da Educação Nova em Portugal, nos campos associativo, do ensino e editorial. Foi professor e diretor da Escola Normal de Lisboa e da Escola Oficina n. ${ }^{\circ}$, estabeleceu a secção portuguesa da Liga Internacional Pró-Educação Nova (1927), fundou e dirigiu a revista Educação Social e participou, desde 1911 até 1930, em diversas comissões encarregadas de elaborar legislação sobre o ensino primário. Foi um dos doutrinadores do anarquismo português e colaborou com a organização sindical na elaboração de teses, nomeadamente sobre educação. Pertenceu à direção da Sociedade de Estudos Pedagógicos e da Universidade Popular Portuguesa ${ }^{68}$.

\footnotetext{
${ }^{65}$ Diário da Câmara do Deputados, sessão de 16 de junho de 1917, 26.

${ }^{66}$ AHS-ICS: Domingos da Cruz, «Retalhos para um livro de memórias...», 1959, fl. 13.

${ }^{67}$ Elementos biográficos recolhidos em: AHS-ICS: Domingos da Cruz...1959, fl. 2-16; FMS: Alexandre Vieira, "Figuras Gradas", s.d. Pasta 09769.142.

${ }^{68}$ AHS-ICS: Espólio de Pinto Quartin, «Curriculum Vitae de Adolfo Lima», s.d. [1942], PT-AHS-ICS-PQCP-201; Bandeira 1994, vol. 2, 138-139; Nóvoa 2003, 736-746.
} 
A experiência na Voz do Operário redundou num fracasso e Lima acabou por apresentar a demissão, em julho de 1930. À data, os serviços estavam numa «grande barafunda» e o professorado às aranhas «por não ter compreendido a nova forma de ensino» ${ }^{69}$. As vozes críticas dentro da CA consideravam que um dos erros do pedagogo foi modificar a estrutura do ensino a meio do ano e em classes que haviam começado com outros métodos. Os desentendimentos ocorriam com os professores, que continuavam a lecionar à revelia das orientações do seu chefe, com os pais, que não compreendiam porque os filhos tinham tantos recreios, não estudavam por livros, não tinham explicações nem trabalhos escolares para fazer em casa. E receavam, pais e professores, que os alunos não se habilitassem para o exame final. Entre outros problemas, a CA decide que não se nomeará outro chefe e que se iria refletir sobre a possibilidade de executar o programa pedagógico, rodeando-se o secretário da Instrução de pessoas qualificadas para o efeito. Neste espaço de tempo, de avaliação e reflexão, as escolas retomariam o modelo de ensino antigo e as aulas inovadoras, montadas por Lima - lavores, modelação e desenho - seriam incorporadas no funcionamento das classes primárias ${ }^{70}$.

Adolfo Lima, no verão de 1929, logo após ser nomeado chefe dos serviços escolares, refere-se ao trabalho em que está envolvido na Sociedade, manifestando certa incredulidade, pela situação que foi encontrar: só a escola privativa n. ${ }^{\circ} 1$ (na sede) tinha 612 alunos e 13 professores e havia mais 28 escolas, espalhadas pela cidade, com perto de 3000 crianças. Salientava ainda a desorganização que foi encontrar nos serviços administrativos e pedagógicos (Candeias, Nóvoa e Figueira 1995, 127). Uma realidade bem diferente da Escola Oficina n. ${ }^{\circ}$ 1, onde Adolfo Lima conquistou fama por estar associado à organização de um modelo alternativo de ensino bem-sucedido, muito anterior a esta nova experiência (1906-1915). Nos períodos de maior afluência de alunos, as inscrições no início do ano letivo rondavam as oito dezenas (Mogarro e Andrade 2019, 191-192). Apesar destas dificuldades, A. Lima confessa que já tinha montado uma aula de modelação e de Desenho, outra de Trabalhos Manuais, e esperava montar ainda naquele ano um gabinete de Física e um Laboratório de Química. Sublinha ainda que na Sociedade existem seções femininas nos cursos noturnos e que ele tem muito empenho em as desenvolver e valorizar. Mas um ano decorrido, já depois de pedir a demissão, Adolfo Lima confessa que, quando aceitou o cargo, suspeitava que nada conseguiria fazer, mas aceitou não se fosse enganar. Mas enganou-se, conclui, porque a sua ação não era útil e perdia-se entre a rotina da Sociedade, anuladora de qualquer inovação:

«A Voz do Operário tem atrás de si, como um grande penedo inamovível o Passo rotineiro da simbólica "carreta fúnebre".

O que a preocupa é a quantidade de alunos e não a qualidade do seu ensino e educação. O ideal é o examezinho e não o saber, a higiene mental. E por mais que se queira remar contra a maré não é possível fazer coisa alguma de jeito. Eu fui esmagado, o Domingos da Cruz foi igualmente esmagado [...].

Demais: se os burgueses patrões são custosos de aturar, vexam e fazem mal aos nervos pela sua estupidez, muito mais custam a aturar os operários patrões. O nosso "bom camaradinha" arvorado em mandão é cem vezes mais autoritário e malcriado do que o mais burguês dos burgueses!» ${ }^{71}$

\footnotetext{
${ }^{69}$ ANTT: SIBVO, Comissão Administrativa, ata n. ${ }^{\circ}$ 14, 23.09.1930, fl. 432.

${ }^{70}$ ANTT: SIBVO, Comissão Administrativa, ata n. ${ }^{\circ}$ 14, 23.09.1930, fl. 432-439 e Esteves 1933b, 46-53.

${ }^{71}$ AHS-ICS: Carta para Pinto Quartin, de 15.11.1930. PT-AHS-ICS-PQ-CP-201.
} 
O regulamento suspenso apenas atendia ao ensino primário e aplicava-se às escolas existentes. Tal como se determinava no Programa Pedagógico, o ensino profissional mantinhase em estudo e a sua organização condicionada aos recursos da Sociedade (Base 16. ${ }^{\mathrm{a}}, \S 2 .^{\circ}$ ).

Da gerência de 1931/32 saiu então uma proposta para um novo regulamento, apresentado à CA pela subcomissão, em 1932 72 . Uma proposta ambiciosa, organizada em 20 títulos e 662 artigos e que seguia o Programa Pedagógico. Todavia, conferia-lhe outro desenvolvimento, clarificava os objetivos a atingir e detalhava aspetos curriculares e metodológicos que não podemos aqui explanar face à extensão das informações. Atenda-se à ideia central.

O regulamento constrói-se a partir de um desiderato: a intenção de educar as novas gerações dentro da «ideologia da Sociedade» e segundo um plano de conjunto que ditava o fim a atividades dispersas. Assim, os programas, a admissão dos professores e a educação dos alunos deveriam «respeita[r] os princípios ideológicos da Coletividade» ${ }^{73}$. E para isso, era necessário subtrair as crianças e os jovens à influência da família e colocá-las sob a influência da Sociedade durante todo o seu período de formação. Para este fim, propõe-se uma ordenação do ensino por graus e níveis etários, correspondentes à conceção de educação integral, realizada por métodos e processos ativos, subjacente ao programa, em associação com a proteção da criança e com a duração da escolaridade necessária para preparar um aluno para enfrentar a vida.

Esta educação iniciava-se na creche, destinada a recolher crianças, a partir de um mês de idade até aos 3 anos, durante o período de trabalho das mães. Seguia-se a educação infantil, a partir dos 4 anos, dirigida para o robustecimento físico da criança (cuidados com a alimentação e com a higiene, atividades físicas ao ar livre), para a aquisição de hábitos, de aptidões e de estímulos intelectuais e sociais, de forma gradual e de acordo com idade. Com o objetivo de «fornecer à criança os fundamentos de todo o saber e as bases duma cultura geral, preparando-a para a vida social» ${ }^{74}$, iniciava-se o ensino primário aos 7 anos, em regime de coeducação, continuado pelo ensino complementar, frequentado nas mesmas condições entre os 12 e os 14 anos. Este grau de ensino estava dirigido para o despiste de aptidões e vocações e a sua frequência era obrigatória para aceder aos cursos profissionais. Por fim, vinha o ensino de uma profissão, distribuído por diversos cursos com a duração de 3 ou 4 anos, frequentados entre os 14 e os 16/18 anos de idade, em regime diurno e com separação dos sexos ${ }^{75}$.

O regulamento estabelecia ainda a criação de um ensino especial, a funcionar junto das classes de ensino primário, com aulas para anormais e para recuperação de atardados, bem como cursos de extensão universitária para a educação social e cultural dos adultos.

$\mathrm{O}$ documento foi aprovado por unanimidade na CA. Antes de ser submetido a discussão na $\mathrm{AG}$, o presidente da $\mathrm{CA}$ decide apresentá-lo em reunião geral de corpos gerentes, para a qual convidou membros de outras gerências ${ }^{76}$. Transita para a comissão de pareceres, que, após ouvir conceituadas opiniões, resolveu divulgar o projeto entre os sócios, deixando diversos exemplares na biblioteca. Sete meses depois ainda o regulamento estava em leitura na comissão ${ }^{77}$. A partir daqui, perde-se o rasto.

Cabe elucidar que o Regulamento de 1932 é da autoria de Mariano Roque Laia (1903 1996) ${ }^{78}$, um advogado, republicano e maçon, também professor da Casa Pia, e que havia iniciado colaboração com a Voz do Operário, ainda jovem, como professor do curso primário

\footnotetext{
${ }^{72}$ ANTT: SIBVO, Relatório apresentado pela Subcomissão de Instrução e Beneficência em Março de 1932.

${ }^{73} \mathrm{Idem}$, fl. s/n. ${ }^{\circ}$, preâmbulo ao regulamento.

${ }^{74}$ Idem, artigo $100 .^{\circ}$

${ }^{75}$ Cursos a criar: precetora, economia doméstica e de governo da casa, costureira de roupa branca, modista de chapéus e modista de vestidos, para a educação da mulher. Cursos de estucador-formador, de serralheiro, de marceneiro, de encadernador, de compositor tipográfico e de impressor para o futuro operário.

${ }^{76}$ ANTT: SIBVO, Comissão Administrativa, atas n. ${ }^{\circ} 36,23.03 .1932$, fl. 137-138; Corpos Gerentes, ata de 4.04.1932, fl. $10-11$

${ }^{77}$ ANTT: SIBVO, Corpos Gerentes, atas n. ${ }^{\circ} 20,2.06 .1932$, fl. 36; n. ${ }^{\circ} 23,3.02 .1933$, fl. 39-40.

${ }^{78}$ Idem, ata de 4.04.1932, fl. $10 \mathrm{vs}$.
} 
noturno, no início da década de 1920, abandonando o cargo, já como diretor, em 1928. É nele que recai a escolha para preencher o lugar de Adolfo Lima. Era necessário dar continuidade à aplicação do Programa Pedagógico e Roque Laia, segundo o presidente da CA da gerência de 1931/32, inscrevia-se no perfil desejado:

«Conhecedor das novas teorias e preceitos pedagógicos, capaz de as realizar sem, contudo, comprometer a regularidade da evolução, nem absorvido pela abstração do gabinete, nem um prático que empiricamente atuasse, nem tão atrasado ideologicamente que fosse um perigo para a ação associativa, nem um político tanto em evidência que fizesse do ideal político a determinante da sua conduta.» (Esteves 1933b, 54-55)

Roque Laia manteve-se na chefia dos serviços escolares entre setembro de 1931 e julho de 1933, quando se demite em contenda aberta com a administração. Teve uma intervenção voluntariosa e, segundo Esteves dos Santos, conseguiu promover recursos e atividades que emprestaram às escolas da Voz do Operário a renovação desejada ${ }^{79}$. E o Regulamento de 1932 resultava desse voluntarismo, mas com um andamento que a associação não conseguia acompanhar. Do seu lado tinha Esteves dos Santos (1889-1954), uma figura central na administração da Sociedade, desde 1929, ano em que assumiu o cargo de presidente do Conselho Fiscal, até ao fim da década de 1940, rodando entre a presidência da mesa da AG, da CA e do conselho fiscal.

Raúl Esteves dos Santos nasceu em Lisboa, numa família operária, abandonou a escola aos 10 anos e educou-se a si próprio. A seguir à I Grande Guerra surgem as referências às primeiras funções públicas, junto de políticos republicanos moderados, tendo passado pelo gabinete de José Relvas (1919) e sido secretário do ministro das Finanças, Peres Trancoso (1921), do governador civil, Agatão Lança (1921-1922) e do ministro do Comércio, Ferreira da Fonseca (1923-1924). Foi funcionário da Câmara Municipal de Lisboa (1925) e desempenhou diversos cargos nos Caminhos de Ferro do Estado (1925-1929). Manteve uma atividade prolixa como escritor e conferencista. Além, como vimos, da produção historiográfica sobre a Voz do Operário, preocupou-se em refletir sobre as causas que ditaram o fim à experiência política republicana ou sobre questões ligadas ao trabalho (propriedade literária, descanso dos trabalhadores, ensino profissional). Fez, a partir de 1931, mais de uma centena de conferências pelo país. Quando morreu, tinha em preparação um volume sobre o associativismo em Portugal, o âmbito da participação cívica que privilegiou, tendo colaborado com diversas coletividades populares ${ }^{80}$.

As mudanças na CA, depois dos confrontos de poder que envolveram o fim da gerência de Esteves dos Santos (1933), suspenderam, mais uma vez, a dinâmica reformadora. Mas no ano seguinte, Emílio Costa (1877-1952) foi contratado para chefe dos serviços escolares. Outra figura de proa do anarquismo em Portugal, como teórico e divulgador, mas também como homem de ação, nomeadamente no campo da educação popular, quer em instituições anarquistas quer em colaboração com as republicanas, como a UPP, quer ainda em associação com o movimento sindical. Era professor do ensino liceal e técnico, dominava as novas correntes pedagógicas, pensava e escrevia sobre educação desde a sua passagem pela Bélgica (Universidade Nova de Bruxelas) e França, entre 1903 e 1908, tendo sido secretário de Francisco Ferrer. Desde 1927 que integrava o quadro de funcionários do Instituto de

\footnotetext{
${ }^{79}$ Horários escolares pelo coeficiente ponogénico das disciplinas, ensino por disciplinas, com relevância para as lições de coisas, criação de aulas de educação física, Desenho, Música, modelação, Trabalhos Manuais, canto coral e lavores, recreios, biblioteca infantil e pedagógica, museu escolar, associações escolares, aquisição de coleções e outros materiais para organizar os gabinetes de ciências, inspeção médica aos alunos (1933b, 58-67).

${ }^{80}$ AHS-ICS: «Homenagem a Raul Esteves dos Santos», 1955. PT-AHS-ICS-PQ-DOC-445.
} 
Orientação Profissional. E é também neste mesmo ano, que Domingos da Cruz volta a integrar a Subcomissão de Instrução, Educação e Arte (gerência de 1934/35). A continuidade da reforma passou pela reposição do regulamento que havia sido suspenso em 1930. Segundo as suas próprias palavras, decalcado daquele que Adolfo Lima tinha elaborado ${ }^{81}$. Entrou em vigor em dezembro de 1935 e manteve-se em vigência até, pelo menos, os anos 50, mas não sem inúmeras dificuldades e incompletudes.

Com efeito, em 1947, a CA alude à necessidade de se retomar o Regulamento de 1935 e no ano seguinte fala-se em dar «continuidade [às] iniciativas de reforma dos serviços de instrução ${ }^{82}$. Em 1949, Domingos da Cruz assume a presidência da CA. No fim da década de 1950, escreve sobre este regresso e a sua experiência na Voz do Operário desde que integrou a Comissão de Sindicância:

«Sofri pelo abandono a que tudo aquilo havia chegado. Esforços renovadores de 1924-1925, canseiras de 1929 a meados de 1930, retomadas em 1934 a 1936, mas nestes dois últimos períodos sem responsabilidades directivas, que recusei, mas não podendo eximir-me a fazer parte da Comissão de Instrução, por insistentes e reiteradas solicitações, quase tudo se havia perdido. Encontrei a Sociedade com dívidas, não deficits, repare-se bem, de algumas dezenas de contos, tudo sujo por dentro, mobiliário deficiente e em péssimo estado, o pessoal menor com os seus fardamentos rotos, todo o pessoal mal pago, etc, etc, como pode ver-se dos relatórios das minhas gerências. Nem assistência escolar, nem biometria, nem fichas, uma ginástica a fingir de educação física para crianças, o diabo.» ${ }^{\mathbf{8 3}}$

\section{Notas conclusivas}

A ideia da reforma educativa foi forçada, em meados da década de 1920, por uma crise na Sociedade e propulsionada pelos efeitos de uma intervenção à margem do funcionamento normal da instituição, resultado da interferência reguladora do Estado sobre as associações, nomeadamente quando lhes reconhecia utilidade pública e lhes conferia benefícios. Esta regulação era de natureza administrativa e financeira, mas também de controlo político "à distância". Como vimos, favorecer a pluralidade de influências políticas, permitia abrir o espetro ideológico e, a par das correntes mais adversas ou com propostas sociais mais radicais entravam também as republicanas, progressistas, mas com uma perspetiva reformista, de integração das classes populares. Com a renovação dos quadros associativos, esperava-se a revitalização de políticas e de iniciativas no campo educativo e no da assistência social, vistas pelo Estado republicano como complementares à sua governação. Já as organizações anarquistas e sindicais, e a prazo as comunistas, esperavam preparar, pela educação política, social, profissional e associativa, as classes trabalhadoras para a futura revolução social.

Efetivamente, com a reforma administrativa (1926), a Sociedade, dentro do modelo associativo de gestão e decisão, pôde renovar os seus quadros e, ao mesmo tempo, dotar-se de mecanismos para implementar uma outra política educativa e social. Assim, para elaborar e apreciar, contava com sócios de todas as categorias, recrutados nas elites operárias, intelectuais e artísticas e provenientes de um espetro social, político e cultural diverso; para executar, dispunha de um corpo de funcionários, docente e administrativo; para dirigir e fazer

\footnotetext{
${ }^{81}$ AHS-ICS: Domingos da Cruz, «Retalhos...», fl. 13; Sociedade ....1935.

82 ANTT: SIBVO, Relatório e contas...1947 e 1948.

83 AHS-Projeto MOSCA: Domingos da Cruz, «Algumas de entre tantíssimas outras peças de um misero processo, originado em vilíssimo relatório...», fl s/n. ${ }^{\circ}$.
} 
aprovar, um grupo mais ativo de sócios, de raiz operária, relativamente circunscrito, que compunha os diversos corpos gerentes por rotação e alternância; para aprovar, uma assembleia geral de sócios, também de número relativamente reduzido e maioritariamente composta pelos associados mais militantes e ativos, agrupados por cumplicidades pessoais, profissionais e políticas; e por fim, tinha uma população associativa de milhares de sócios, em decrescimento, cujas cotas constituíam a receita essencial e que havia que renovar com novas adesões, assim como corresponder às suas expetativas sociais ${ }^{84}$.

Apesar dos avanços, retrocessos e impasses, o modelo educativo que se elaborou e colocou parcialmente em prática, saiu de um grupo restrito de sócios, de influências ideológicas distintas, mas convergentes na importância que davam ao associativismo, como forma de organização e participação cívica, e a uma nova educação, com organizações, métodos e práticas de conformar a escola e o ensino, primário e profissional, assim como a educação social de adultos, dentro do modelo das universidades populares.

Semelhante programa destinava-se, sobretudo, às classes populares, desfavorecidas, e procurava-se a montante, combater o flagelo social da doença e da pobreza, e a jusante, valorizá-las com uma profissão, adequada à suas vocações e aptidões. $\mathrm{O}$ fio que unia o percurso estabelecia-se numa conceção de escola única, dos 4 aos 16 anos, que apostava numa formação intelectual, social e cultural, criadora de espíritos com iniciativa, e iniciados na vida social - que a escola reproduzia -, nomeadamente através do ensaio de práticas de previdência e de solidariedade. De salientar, por fim, que o modelo desenhado se centrava, em particular, na promoção do desenvolvimento físico do aluno (alimentação, atividade física, gestão do tempo escolar, recreios, colónias de férias, fiscalização da saúde, despiste de doenças e anomalias, adequação do trabalho escolar às capacidades do educando, avaliação das aptidões e orientação profissional) e colocava o médico escolar e a observação médico-psicopedagógica no centro da escola e do ensino. Os cursos profissionais respondiam à cadeia final deste processo.

O modelo não era original. Mas era inovador, por ser proposto por uma associação de trabalhadores e funcionar num circuito fechado. Incorporava conceções da Educação Nova que, no fim da década de 1920, repassavam com intensidade para o movimento operário e para organizações de professores muito alinhadas com o sindicalismo revolucionário e com o anarquismo, como a Associação de Professores de Portugal, a Liga de Ação Educativa e a União dos Professores Primários. Conceções que influenciavam ainda iniciativas republicanas e até governamentais e municipais. Encontram-se neste casos: o projeto de Reforma da Instrução Pública, apresentado pelo ministro João Camoesas em 1923, que nunca foi discutido no parlamento, mas que relançou o debate sobre a Escola Única e foi muito bem acolhido por aqueles associações e por Adolfo Lima e Emílio Costa (Nóvoa 1986, 114-115); o projeto de Alexandre Ferreira, como vereador da Câmara Municipal, de constituição de uma escola primária tipo ${ }^{85}$; e o programa educativo para os estabelecimentos de educação da assistência pública, em regime de internato ${ }^{86}$. Todos estes programas foram elaborados por Faria de Vasconcelos, o pedagogo português, nascido cientificamente no seio do Movimento da Educação Nova, colaborador próximo de Ferrière, e fundador e diretor do Instituto de Orientação Profissional (Nóvoa, 2003, 1397-1404) ${ }^{87}$. E de todos, por vezes no seu próprio articulado, se colheram

\footnotetext{
${ }^{84}$ Entre 1934/35 e 1940, as cotas dos cerca de 60 mil associados representavam, em média, $74 \%$ das receitas (SIBVO, Relatório e contas...1935 a 1940). Como referência mínima, aponte-se que a cidade de Lisboa tinha em 1930 e 1940, respetivamente, 594390 e 694389 habitantes residentes. E em 1940, destes, 73868 com idades entre 7 e os 13 anos, e 77 747, nos níveis etários entre os 14 e 19 anos (Instituto Nacional de Estatística, 1940).

${ }^{85}$ Faria de Vasconcelos, «Bases para uma escola primária tipo municipal [inclui jardim de infância e campos de jogos]», programa elaborado a pedido de Alexandre Ferreira, enquanto vereador da CML. In Obras Completas. Lisboa: FCG, 2006, vol. III, 477-487).

${ }^{86}$ Decreto n. $^{\circ} 12911$, Diário do Governo, n. ${ }^{\circ} 290,28.12 .1926$.

${ }^{87}$ Não podemos garantir que lhe pertence o programa dos internatos da assistência. Mas face ao conteúdo, e à ligação de Faria de Vasconcelos à Direção Geral da Assistência, da qual dependia o Instituto de Orientação
} 
influências para os programas e regulamentos da Voz do Operário. Com exceção de Faria de Vasconcelos, nas subcomissões estiveram, como vimos, Camoesas ${ }^{88}$, mas também Alexandre Ferreira, um republicano, fundador de uma universidade popular e vereador municipal nos anos 20, onde desenvolveu obra na educação e assistência. Assim como entre os professores, figuras que provinham de redes de sociabilidade profissional e científica, geradas em torno do Instituto de Orientação Profissional, ou da Casa Pia de Lisboa, um estabelecimento de assistência a menores.

Mas sobre os circuitos dos saberes na inovação pedagógica em Portugal e, em particular, na forma como enformaram a reforma dos serviços escolares na Sociedade de Instrução e Beneficência A Voz do Operário, teremos de deixar para uma abordagem mais circunstanciada.

\section{Referências}

Arquivo Histórico-Social/Projeto MOSCA - Espólio Adelino Augusto Ferreira. Disponível em http://mosca-servidor.xdi.uevora.pt/projecto/index.php?option=com_jumi\&fileid=7\&p=collections

Arquivo de História Social-ICS - Espólio Pinto Quartin, parcialmente disponível em http://www.ahsocial.ics.ulisboa.pt/atom/espolio-pinto-quartin, último acesso 22.02.2019

ANTT, Fundo da Sociedade de Instrução e Beneficência A Voz do Operário, disponível em https://digitarq.arquivos.pt/details?id=4641905, último acesso 30.04.2018.

Assembleia Geral, Atas da, 1917-1925, 1925-1928, 1932-1934, 1934-1935.

Biblioteca Infantil, 1937/1939.

Comissão de Pareceres, Atas da, 1926-1955.

Corpos Gerentes, Atas dos, 1928-1956.

Comissão Administrativa, Atas da, 1924-1925, 1925-1928, 1928-1930, 1930-1934, 1934-1937.

Domingos Cruz, espólio de [correspondência, décadas 1920-1950].

Livro de Autos e Ocorrências, 1931-1934.

Relatório apresentado pela Subcomissão de Instrução e Beneficência em Março de 1932.

Relatório do Chefe dos Serviços Escolares, Augusto Alberto Sanches, 18.08.1938.

Relatório e contas e parecer do Conselho Fiscal. Gerência de ... 1934/35 a 1965.

FMS (Fundação Mário Soares. Casa Comum) - Fundo de Alberto Pedroso, disponível em http://casacomum.org/cc/arquivos, último acesso 02.04.2019.

\section{Fontes impressas}

Brocas, Manuel de Araújo. 1938. A Biblioteca de A Voz do Operário: 1888-1938. [S.1. : s.n.].

Cruz, Domingos da. 1947. O Ensino em Portugal. Alguns números e comentários em prol do ensino profissional. Lisboa: s.n.

Profissional, e ainda à colaboração que prestou aos Serviços Jurisdicionais de Menores, igualmente no âmbito da organização dos internatos da Justiça, cremos pertencer-lhe a autoria (sobre a colaboração com o Ministro da Justiça, vd. Bandeira 2016, 121-122.

${ }^{88}$ Era também colaborador do IOP, onde, desde 1925, dirigia os serviços de Fisiologia (Nóvoa 2003, 237 241). A sua participação na SCIEA, gerências de 1927/28 e 1928/29, cessou pela sua prisão, seguida de deportação para Angola (1928), por atividade política contra a Ditadura Militar (ANTT: SIBVO, Corpos Gerentes, ata de 7.05.1928, fl. 3 vs). Exilado nos EUA, a partir de 1929, viria neste país a organizar a oposição ao Estado Novo (Pena-Rodríguez 2016, 427). Outros dirigentes da Voz do Operário conheceram, nestes anos iniciais da Ditadura Militar, a prisão, como Esteves dos Santos, e mesmo a deportação, como Domingos da Cruz. 
Diário da Câmara dos Senhores Deputados, 1911-1921. http://debates.parlamento.pt/, último acesso em 22.02.2019.

Instituto Nacional de Estatística. 1945. VIII Recenseamento Geral da População no Continente e Ilhas Adjacentes em 12 de Dezembro de 1940. Lisboa: Imprensa Nacional.

Santos, Raúl Esteves dos. 1932 b. «A Voz do Operário, Grande Seara de Luz.» Almanaque Pensamento, 1:174-181.

Santos, Raúl Esteves dos. 1933 a. A Grande Epopeia dos Humildes. Lisboa: SIBVO.

Santos, Raúl Esteves dos. 1933 b. Três Anos na Grande Colmeia. Lisboa: edição do autor.

Santos, Raúl Esteves dos. 1936. Figuras Gradas da Voz do Operário. Lisboa: SIBVO.

Santos, Raúl Esteves dos 1938. «A história da Voz do Operário». Gazeta dos Caminhos de Ferro, 1204: 97-99.

Santos, Raúl Esteves dos 1947. O Ensino Técnico e Profissional sobre o Ponto de Vista Histórico. Lisboa: SIBVO.

Sociedade de Instrução e Beneficência A Voz do Operário. 1926. Estatutos e Regulamento Interno. Lisboa: Tip. De A Voz do Operário.

Sociedade de Instrução e Beneficência A Voz do Operário. 1931. Estatutos e Regulamento Interno. Lisboa: Tip. De A Voz do Operário.

Sociedade de Instrução e Beneficência A Voz do Operário. 1935. Programa Pedagógico, Bases Orgânicas das Associações Escolares e Regulamento dos Serviços Escolares. Lisboa: Tip. Privativa de A Voz do Operário.

\section{Bibliografia}

Bandeira, Filomena. 1994. «A Universidade Popular Portuguesa nos Anos 20. Os intelectuais e a educação do povo: entre a salvação da república e a revolução social». Tese de Mestrado. Universidade Nova de Lisboa. Disponível em http://hdl.handle.net/10362/14306.

Bandeira, Filomena. 2016. «Augusto Oliveira, um realizador». In Mais Figuras do Judiciário, séculos XIX-XX, coordenação de Luís Eloy Azevedo, 105-126. Lisboa: Almedina.

Baptista, Virgínia do Rosário, 2016. «As associações de socorros mútuos em Portugal (de finais do século XIX aos anos quarenta do século XX).». Em Espaços, Redes e Sociabilidades: Cultura e política no movimento associativo contemporâneo, coordenação de Joana Dias Pereira, Maria Alice Samara e Paula Godinho, 95-106. Lisboa: IHC.

Candeias, António, António Nóvoa e Manuel Henrique Figueira. 1995. Sobre a Educação Nova: Cartas de Adolfo Lima a Álvaro Viana de Lemos (1923-1941). Lisboa: Educa. 
Candeias, António. 2013. «Ensino livre.» In Dicionário de História da I República e do Republicanismo, coordenação de M. Fernanda Rollo, 1184-1188. Lisboa: Assembleia da República, vol. 1.

Carvalho, David Luna. 2013. «Voz do Operário.» In Dicionário da I República e do Republicanismo, coordenação de Maria Fernando Rollo, 1142-1143. Lisboa: Assembleia da República, vol. 3.

Christen, Carole \& Laurent Besse. 2017. «Retracer l'histoire de l'éducation populaire (18151945).» Histoire de l'éducation populaire - 1815-1945 - Perspectives françaises et internationales, dir. C. Christen \& L. Besse, 11-32. Lille: Presses universitaires du Septentrion.

Folgado, Deolinda (coord.). 2016. Norte Júnior - Itinerários 1905 - 1929. Direção-Geral do Património Cultural, http://www.patrimoniocultural.gov.pt/pt/patrimonio/itinerarios/nortejunior-itinerarios-1905-1929, consultado em 22.02.2019.

Franco, Alfredo. 2018. A Voz do Operário. Sociedade de Instrução e Beneficência A Voz do Operário - 135 anos. Lisboa: Althum.

Freire, João e Maria Alexandre Lousada. 2013. Roteiros da Memória Urbana - Lisboa: marcas deixadas por libertários e afins ao longo do século XX. Lisboa: Colibri.

Freire, João. 1992. Anarquistas e Operários. Lisboa: Edições Afrontamento.

Freire, João. 2012. Dicionário Histórico de Militantes Sociais, Grupos Libertários e Sindicatos Operários. Documento digital. Disponível em http://moscaservidor.xdi.uevora.pt/projecto/index.php?option=com_content\&view=article\&id=33\&Itemid=45

Galhordas, Maria Emília e Carlos Damas. 1992. Tradição Centenária a Par com o Nosso Tempo: contribuição para a história da "Voz Do Operário". Lisboa: Voz do Operário.

Galvão, Andreia e José Ribeiro Mendes. 2011. «Filantropia e Arquitectura: da $1^{\text {a }}$ República ao Estado Novo (1880-1920).» Revista Arquitectura Lusíada, 2 (1. ${ }^{\circ}$ semestre): 19-32.

León, Antoine. 1983. Histoire de l'Éducation Populaire en France. Paris: Fernand Nathan.

Lopes, Ramiro José Ferreira, 1995. «Sociedade de Instrução e Beneficência: “A Voz do Operário": uma associação representativa da classe dos manipuladores de tabaco, em particular, e da classe operária, em geral.» Tese de mestrado em Antropologia Cultural e Social da Cultura. Universidade Nova de Lisboa.

Lousada, Maria Alexandre. 2017. «O 'espírito de associação' em Portugal. Dinâmica social e legislação (1820-1926).» In Anarquismo, Trabalho e Sociedade. Livro de homenagem a João Freire, AA.VV, 97-119. Lisboa: Almedina.

Martín López, David. 2014. La estética masónica en Lisboa: nuevas perspectivas para historiar la cuidad. Revista de História da Arte, n. ${ }^{\circ} 11$, pp. 267-281.

Melo, Daniel. 2008. «Estado e sociedade civil em Portugal: leitura pública, educação popular e política cultural (1870-1950).» In Transformações Estruturais do Campo Cultural Português, 1900-1950, coordenação de António Pedro Pita e Luís Trindade, 135-161. Coimbra: CEIS20. 
Mesquita, Maria Cristina. 1987. «"A Voz do Operário”, dados quantitativos.» Análise Social, $3(\mathrm{~V}): 375-386$.

Mogarro, Maria João e Alda Andrade. 2019. «Uma escola no seu tempo: a Escola Oficina n. ${ }^{\circ} 1 »$. Em Roteiros de Inovação Pedagógica. Escolas e experiências de referência em Portugal no século XX, coordenação de Joaquim Pintassilgo e Luís Alberto Marques, 167201. Lisboa: UL-IE.

Nóvoa, António (coord.). 2003. Dicionário de Educadores Portugueses. Lisboa: edições ASA.

Nóvoa, António. 1986. «O projeto de reforma Camoesas (1923): uma referência histórica no pensamento do prof. João Evangelista Loureiro.» Revista da Universidade de Aveiro 7 (1-2): 113-119.

Paixão, Maria da Conceição L. 1989. «Norte Júnior: Obra Arquitetónica.» Tese de mestrado. Universidade Nova de Lisboa, Faculdade de Ciências Sociais e Humanas.

Paulus, Pascal. 2013. «Uma Outra Forma de Fazer Escola. A Voz do Operário de Ajuda.» Tese de doutoramento. Universidade de Lisboa, Instituto de Educação.

Pena-Rodríguez, Alberto. 2016. «El exilio político portugués en Estado Unidos: prensa y propaganda (1930-1945).» Em A Cultura do Poder. A Propaganda nos Estado Autoritários, coordenação de Alberto Pena-Rodríguez e Heloísa Paulo, 413-435. Coimbra: Imprensa da Universidade de Coimbra. https://doi.org/10.14195/978-989-26-1064-1_18

Pereira, Joana Dias. 2009. «A ofensiva operária». História da Primeira República Portuguesa, coord. Fernando Rosas e Maria Fernanda Rollo, 421-440. Lisboa: Tinta da China.

Pintassilgo, Joaquim. 2007. A Educação Nova em contexto republicano. Algumas reflexões a propósito da atividade da Sociedade de Estudos Pedagógicos. http://hdl.handle.net/10451/4009, consultado em 24.04.2019.

Pintassilgo, Joaquim. 2011. O Público e o Privado na História da Educação - o exemplo de Portugal ( $2^{a}$ metade do século XIX - início do século $\left.X X\right)$. https://repositorio.ul.pt/bitstream/10451/8351/1/O\%20P\%C3\%BAblico\%20e\%20o\%20Privado.pdf

Pintassilgo, Joaquim. 2012. Experiências republicanas e intervenções educativas (o exemplo da I República Portuguesa, 1910-1926). https://repositorio.ul.pt/bitstream/10451/10732/1/Experi\%c3\%aancias\%20republicanas.pdf

Santos, Fernando Piteira. 1983. O Centenário da Sociedade A Voz do Operário. Lisboa: Voz do Operário.

Tavares, David e Manuel Pimenta. 1987. «O ensino não oficial na Primeira República - ”A Voz do Operário".» Análise Social, 3 (V): 363-374. 